WORKING

PAPER SERIES

ON REGIONAL

ECONOMIC

INTEGRATION NO. 18
Global Financial Turmoil: Impact and Challenges for Asia's Financial Systems 



\section{Global Financial Turmoil: Impact and Challenges for Asia's Financial Systems*}

April 2008
Jong-Wha Lee ${ }^{+}$and Cyn-Young Park ${ }^{++}$

"We thank Yung Chul Park, Doo Yong Yang and other participants in the Asian Economic Panel Meeting, Seoul, Korea, 25-26 April 2008 for helpful comments and also the research assistance of Arnelyn Abdon, Anthony Baluga, Josephine Duque, Ernalyn Lising and Fidelis Sadicon. The views expressed in this paper are the authors' and do not necessarily reflect the views and policies of the Asian Development Bank, its Board of Directors, or the governments ADB's members represent.

+ Office of Regional Economic Integration, Asian Development Bank, 6 ADB Avenue, Mandaluyong City, 1550 Metro Manila, Philippines. Tel.: 632-632-4900, E-mail: jwlee@adb.org.

${ }^{++}$Corresponding author. Office of Regional Economic Integration, Asian Development Bank, 6 ADB Avenue, Mandaluyong City, 1550 Metro Manila, Philippines. Tel.: 632-632-5473, E-mail: cypark@adb.org.

\section{Asian Development Bank}


The ADB Working Paper Series on Regional Economic Integration focuses on topics relating to regional cooperation and integration in the areas of infrastructure and software, trade and investment, money and finance, and regional public goods. The Series is a quick-disseminating, informal publication that seeks to provide information, generate discussion, and elicit comments. Working papers published under this Series may subsequently be published elsewhere.

Disclaimer:

The views expressed in this paper are those of the author and do not necessarily reflect the views and policies of the Asian Development Bank or its Board of Governors or the governments they represent.

The Asian Development Bank does not guarantee the accuracy of the data included in this publication and accepts no responsibility for any consequence of their use.

Use of the term "country" does not imply any judgment by the authors or the Asian Development Bank as to the legal or other status of any territorial entity.

Unless otherwise noted, \$ refers to US dollars.

(C) 2008 by Asian Development Bank

April 2008

Publication Stock No. PPA202308 


\section{Contents}

Abstract

I. Introduction 2

II. The Recent Turmoil and Background

III. Impact on Asian Financial Markets and Further Potential Spillover
A. Impact

B. Channels of Further Financial Contagion

IV. Challenges from the Changing Financial Landscape

A. Financial Innovation and Asian Financial Systems

B. Global Financial Integration and Spillover

V. Policy Implications

References

Appendixes

1. Data Description

2. Empirical Methodology

A. Equity Markets

B. Bond Markets

27

3. Specification Issues

ADB Working Paper Series on Regional Economic Integration

Tables

1A. Nonperforming Loans (\% of Commercial Bank Loans) 9

1B. Risk-Weighted Capital Adequacy Ratios (\% of Risk-Weighted Assets)

1C. Rate of Return on Commercial Bank Assets (\% Per Annum) 10

2. Growth of Bank Credit to Private Sector (y-o-y, \%) 11

3. Composition of Bank Lending (as \% of Total Domestic Credit) 12

4. Household Indebtedness (\% of GDP) 12

5. Total Portfolio Investment Liabilities (\$ Billion) 14

6. Size of Markets for Institutional Investors in Integrating Asian Economies (2006) 


\section{Figures}

1. US Subprime Delinquencies by Vintage Year (60+ Day Delinquencies, in \% of Original Balance)

2. Three-Month LIBOR to Three-Month Overnight Index Swap (OIS) Spreads (Basis Points)

3. US Federal Funds Rate (\%)

4. Morgan Stanley Capital International Indexes (2 Jan 2006=100)

5. Price Earnings Ratio

6. JP Morgan EMBI Sovereign Stripped Spreads

7. Sector Gross External Bond Issuance (\$ Billion)

8. Securities Investment to Total Bank Assets of Commercial Banks (\%)

9. Financial Account ( $\%$ of GDP)

10. Growth of Bank Lending Rate (\%)

11. iTraxx1 Credit Default Swap Spreads (in Basis Points)

12. Total Outstanding Securitization (Emerging East Asia)

13. US Shock Spillover Intensity in Asian Equity Markets

14. Share of Variance in Local Equity Returns Explained by US Shocks (2001-2007)

15. US Shock Spillover Intensity in Asian Bond Markets

16. Share of Variance in 10-Year Local Government Bond Yields Explained by US Shocks (2001-2007) 


\begin{abstract}
This paper examines the unfolding of the US subprime-generated turmoil and its potential spillover on emerging Asia's financial systems. The subprime mortgage mess has revealed key structural weaknesses in the evolution of modern credit markets. While emerging Asian financial markets have thus far suffered only limited impact, they remain open to further contagion given underlying weaknesses in the region's financial systems. Rapid financial globalization also poses new challenges as the region's largely unsophisticated banking and financial systems strive to keep up with the evolving financial environment and innovation. Policy priorities to foster regional financial stability include enhancing transparency and governance, improving risk management, strengthening regulation and supervision, and deepening and broadening financial systems, especially by developing local currency bond markets.
\end{abstract}

Keywords: Trade and financial integration, global and regional integration, risk sharing, East Asia. 


\section{Introduction}

The global financial turmoil originating from the subprime mortgage market in the United States (US) is deepening and broadening. Conditions in global financial markets remain distressed, despite sizable liquidity injections and other emergency measures by the world's major central banks. Markets for short-term funding in the major countries have periodically seized up-with interbank borrowing rates rising to high levels-and financial firms continue to hoard liquidity. But spillover on the Asian financial markets has so far been relatively limited-manifested mainly through equity and US dollar debt markets. The region's banks remain little affected and short-term credit markets show few signs of stress. Domestic funding conditions have been generally positive, therefore, and capital inflows to the region remain strong.

Asian financial markets and systems will most likely continue to weather the current financial turmoil, a few important factors helping explain this resilience. First, the region's financial institutions have relatively small direct exposure to US subprime mortgages and structured credit products. Second, strong growth prospects and sound external positions have continued to support investor confidence in the regional economies. Third, improved policies and continued prudence in most emerging economies help mitigate the impact of external shocks.

These positive factors do not, however, guarantee the complete insulation of the region's financial markets and systems from global financial turbulence, especially if it worsens. Uncertain and unsettled conditions in the external environment will likely continue. Of particular concern, subprime-related losses are still growing worldwide, with investors requiring increasingly higher risk premiums on their holdings of mortgage-based and complex derivative securities. Growing concerns about counterparty credit risk have intensified the strain on funding and market liquidity, although coordinated action by the world's major central banks has eased some of them. Massive write- downs in several major global financial institutions have resulted-for example, in the nationalization of Northern Rock in the United Kingdom, US Federal Reserve (the Fed) assistance in the fire sale of Bear Stearns, and the liquidation of well-known investment funds, including Carlyle Capital.

There are several important channels through which further global instability could transmit to the region's financial markets and affect regional economies. Heightened risk perception and declining investor confidence could trigger a sudden reversal of financial flows from the region's capital markets, pushing down asset prices and intensifying financial market volatility. A swing in market sentiment and a sudden change in liquidity conditions could also affect local financial markets and institutions more directly. Although the region's banking systems reportedly have small direct exposure to subprime and related credit derivatives, there are signs of stress related to increased volatility in asset prices and to rising risk premiums in offshore funding markets. Contagion might affect the region's financial markets more seriously if tightening credit conditions and financial instability weigh on broader economic activity.

This paper examines the evolution of the US subprime-generated turmoil and its spillover onto emerging Asia's financial markets. It assesses the strengths and vulnerabilities of the region's financial systems in the face of rapidly changing global financial market conditions, shedding light on the challenges the region's policymakers may face. Section 2 briefly summarizes recent events surrounding the US subprime turmoil and its background. Section 3 examines the impact so far on regional financial markets and the various channels of further contagion. Section 4 discusses the challenges posed by new trends in financial innovation and globalization to the region's financial systems, which could increase financial vulnerability. Section 5 suggests policy options. 


\section{The Recent Turmoil and Background}

The genesis of the US subprime meltdown in mid-2007 can be traced to the housing boom of 2001-2005. As housing markets thrived amid historically low interest rates, US residential mortgage lending soared, with an increasing portion made to borrowers with less-than-perfect (that is, subprime) credit histories. ${ }^{1}$ Several factors-including the deregulation of the housing finance system in the $1980 \mathrm{~s}^{2}$ the introduction of the automated underwriting system, and the growing use of securitization-also encouraged the rapid development of the subprime mortgage market. Together with increased competition among mortgage lenders that led to lax lending criteria, a proliferation of new types of mortgages- "affordability products" which require little or no down payment and initially carry very low "teaser" rates-allowed subprime borrowers to gain easier access to credit. As a result, the subprime mortgage market grew rapidly after 2003 - according to some estimates it accounted for as much as one fifth of new mortgages by 2006.

Subprime borrowers are typically charged higher interest rates than prime borrowers to compensate for higher default risk, and their mortgages are often at adjustable rather than fixed rates. As the Fed began to raise interest rates in July 2004, these subprime mortgage borrowers naturally faced larger interest payments. The subsequent cooling in the housing market also made it difficult for them to refinance their mortgages into loans with better terms or pay off the mortgages by selling homes. Consequently, delinquencies on subprime mortgages picked up significantly from mid-2005 (Figure 1).

Figure 1: US Subprime Delinquencies by Vintage Year

(60+ day delinquencies, in \% of original balance)

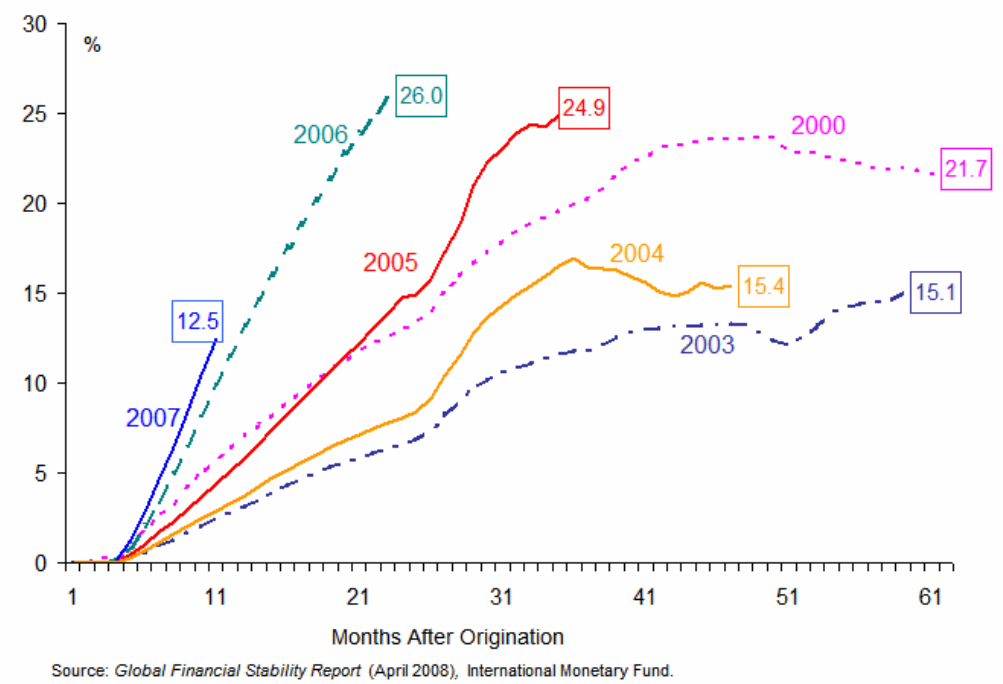

1 Assessment of the borrower's ability to afford repayments on a mortgage is typically based on the borrower's credit history, credit score, debt-to-income (DTI) ratio, and the mortgage loan-to-value (LTV) ratio. Fannie Mae lending guidelines provide benchmarks for what it considers "prime" borrowers on conforming loans in the United States. Prime borrowers have a credit score above 620 (credit scores are between 350 and 850, with a median in the US of 678 and a mean of 723), a DTI ratio no greater than $75 \%$ (meaning that no more than $75 \%$ of net income pays for housing and other debt), and a LTV ratio of $90 \%$, meaning that the borrower is paying a $10 \%$ down payment. Accordingly, borrowers who do not meet these criteria are subprime borrowers by Fannie Mae standards.

2 US federal policy to promote home ownership resulted in some important changes to federal legislation in the 1980s. Key legislation includes the Depository Institutions Deregulatory and Monetary Control Act of 1980, which eliminated all usury controls on first-lien mortgage rates, and the St. Germain Depository Institutions Act of 1982, which allowed adjustable rate mortgages and removed interest rate ceilings for Savings and Loan banks (Institution). The Tax Reform Act of 1986 also made the interest payment on mortgage loans tax deductible. 
Defaults on US subprime mortgages quickly spilled onto the balance sheets of hedge funds and other investment funds. They also affected a number of banks through their off-balance sheet financial "conduits", which invested heavily in related mortgage derivatives and credit products. Proliferation of structured credit products-which helped bundle, repackage, and sell subprime mortgages to a broad spectrum of global investor groups-provided the link for financial contagion. These new credit risk transfer instruments have gained popularity among international financial institutions as a way of boosting profits in an environment of relatively low interest rates, while helping manage risk exposure. In particular, banks set up structured investment vehicles (SIVs) to invest in these higher-yielding or more risky long-term assets, while keeping them off their balance sheets and thus avoiding the need to set aside large regulatory capital. But when asset values declined sharply and liquidity dried up suddenly in the market, SIVs were brought back onto banks' balance sheets.

Uncertainty about the valuation, disclosure of structured products, and rising risk aversion, has since spread the contagion. ${ }^{3}$ As financial institutions have become concerned about counterparty risk and unknown exposure to the subprime mortgages and related credit derivatives, this added pressure on the assessment of risk has driven financial institutions to become very cautious and hoard liquidity. Consequently, strains in short-term funding markets in the US and elsewhere-notably interbank and asset-backed commercial paper marketshave intensified (Figure 2). Major financial firms' credit default swaps widened sharply as risk perception stayed high. Banks' profits have suffered from large write-downs of sub-prime products and the absorption of SIVs formerly involved in subprime markets. Higher levels of financial leverage and significant maturity mismatches implied by the funding of SIVs in subprime-related long-term investments through short-term borrowing remain a major source of vulnerability.

Figure 2: Three-Month LIBOR to Three-Month Overnight Index Swap (OIS) Spreads (Basis Points)

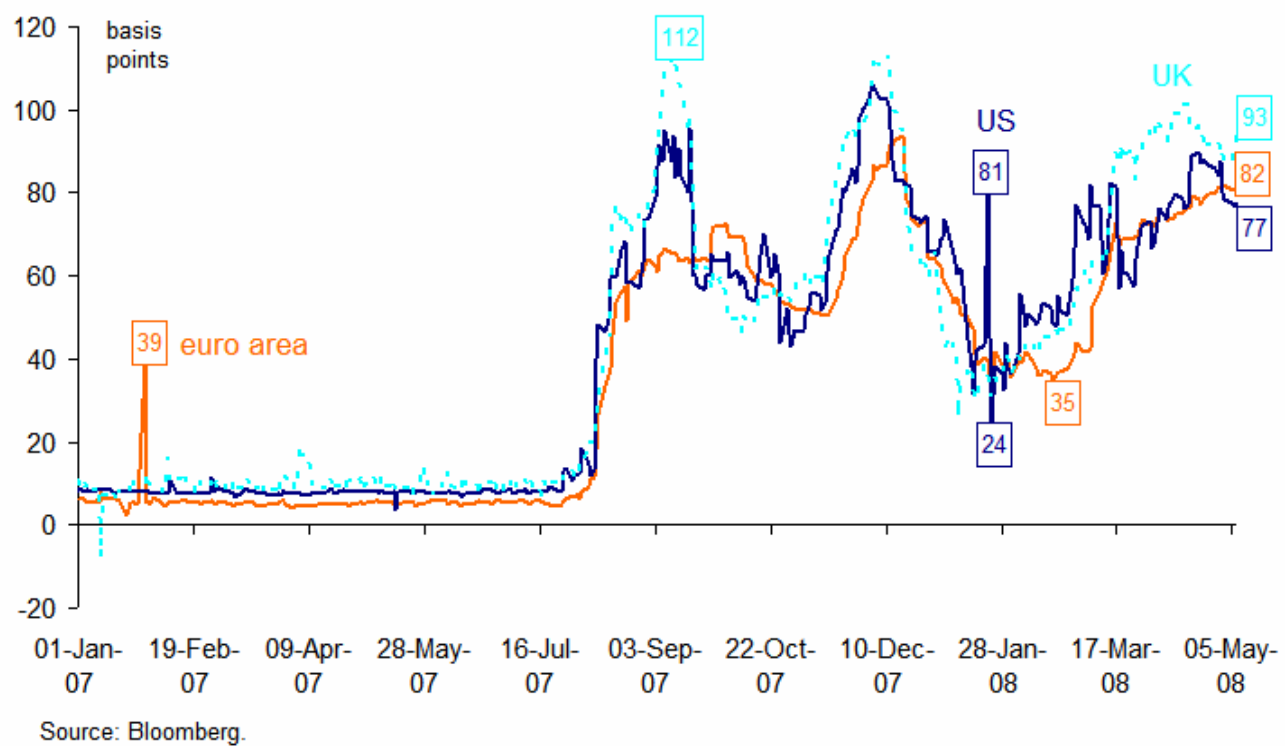

\footnotetext{
3 See IMF (2008) for detailed explanation of issues related to structured finance and market illiquidity.
} 
The subprime mortgage mess has revealed key structural weaknesses in the evolution of modern credit markets. First, the "originate-to-distribute" model of financing made popular by the greater availability of credit transfer instruments has weakened the link between lenders and borrowers. This has diluted incentives to rigorously assess the credit worthiness of the borrower and to monitor the obligor's financial state. Second, growing use of complex structured credit products has increased uncertainty about the valuation of financial assets. The high leverage embedded in these products tends to blur the size of commitment in each layer of securitization, obscuring the degree of risk exposure. Thin-trading of these sophisticated products also makes market-based valuation especially difficult in times of financial distress when market liquidity suddenly dries up. Third, a rise in leverage in the overall financial system has increased vulnerability to a shift in risk perception and changes in liquidity conditions. Increasing reliance on market-driven financial intermediation tends to generate a false sense of liquidity in times of relative market calm. But in a time of distress elevated uncertainty may lead to a collective failure of liquidity provision in the market. In particular, a sharp decline in asset values forces regulated financial institutions to liquidate positions, adding to the liquidity crisis.

Major central banks have taken several measures to restore normal market functioning: these include the injection of large amounts of liquidity, a relaxation of rules to include a broader range of collateral, an extension of maturity on discount lending, and a widened range of counterparties to provide liquidity support (including investment banks in the US). The Fed also set up a new lending facility using Treasury securities. While authorities in the US and Europe have also bailed out high-profile financial institutions with public funds, such as Bear Stearns. In consequence, central banks' balance sheets now reflect much higher levels of subprime-related risk.

On monetary policy, the Fed slashed its target federal funds rate in the wake of the subprime turmoil (Figure 3) - although it has since signaled it has finished cutting rates-while other major central banks have largely stepped back from the previous tightening stances in favor of "waitand-see" strategies. Alongside the still-large US current account imbalance, this saw the US dollar weaken sharply, in particular against the euro and the Japanese yen.

Figure 3: US Federal Funds Rate (\%)

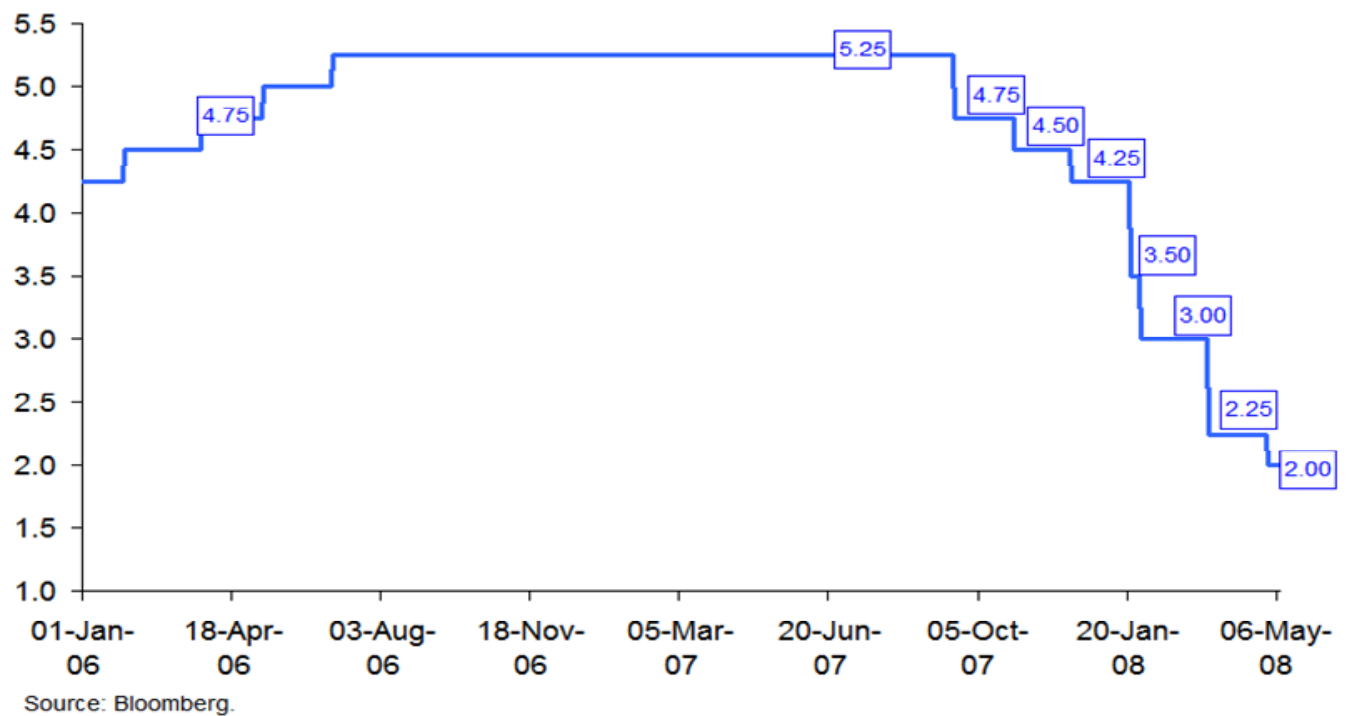




\section{Impact on Asian Financial Markets and Further Potential Spillover}

A. Impact

So far, Asia's financial markets have suffered only limited impact (largely through equity and offshore bond markets) from the subprime-related troubles. Heightened anxiety over increasing subprime losses, deteriorating credit quality, and a slowing global economy have prompted large sell-offs in the region's stock markets (Figure 4). Share prices have tracked losses on the major markets since early 2007-particularly in countries where equities were already quite high. Further significant losses are still possible in some markets where price-earnings ratios remain high (Figure 5). In response, local and foreign firms have postponed plans for new issuance in the equity markets.

Figure 4: Morgan Stanley Capital International Indexes

(2 Jan 2006=100)

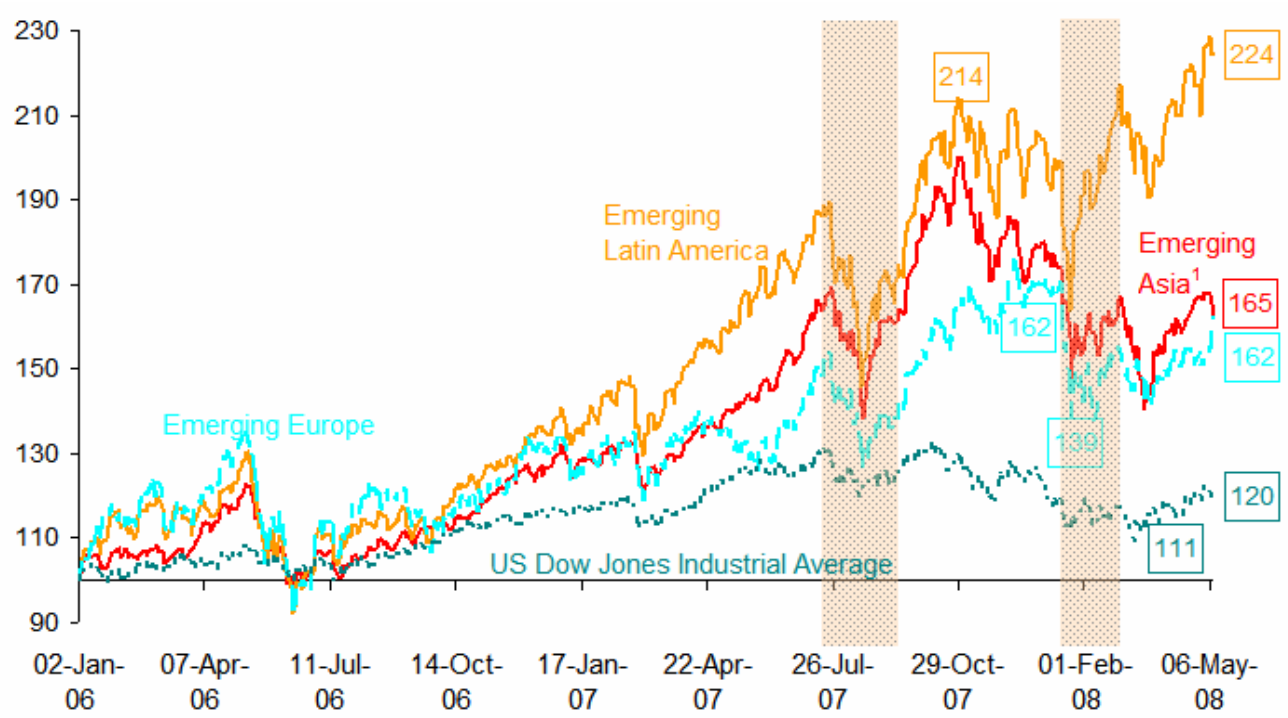

'Includes China, People's Rep. of; India; Indonesia; the Republic of Korea; Malaysia; Pakistan; Philippines; Taipei,China; and Thailand.

Note: shaded areas indicate the periods 15 Jul to 20 Sep 2007 and 14 Jan to 28 Feb 2008 .

Sources: Morgan Stanley Capital International (MSCl) Barra and Bloomberg. 
Figure 5: Price Earnings Ratio

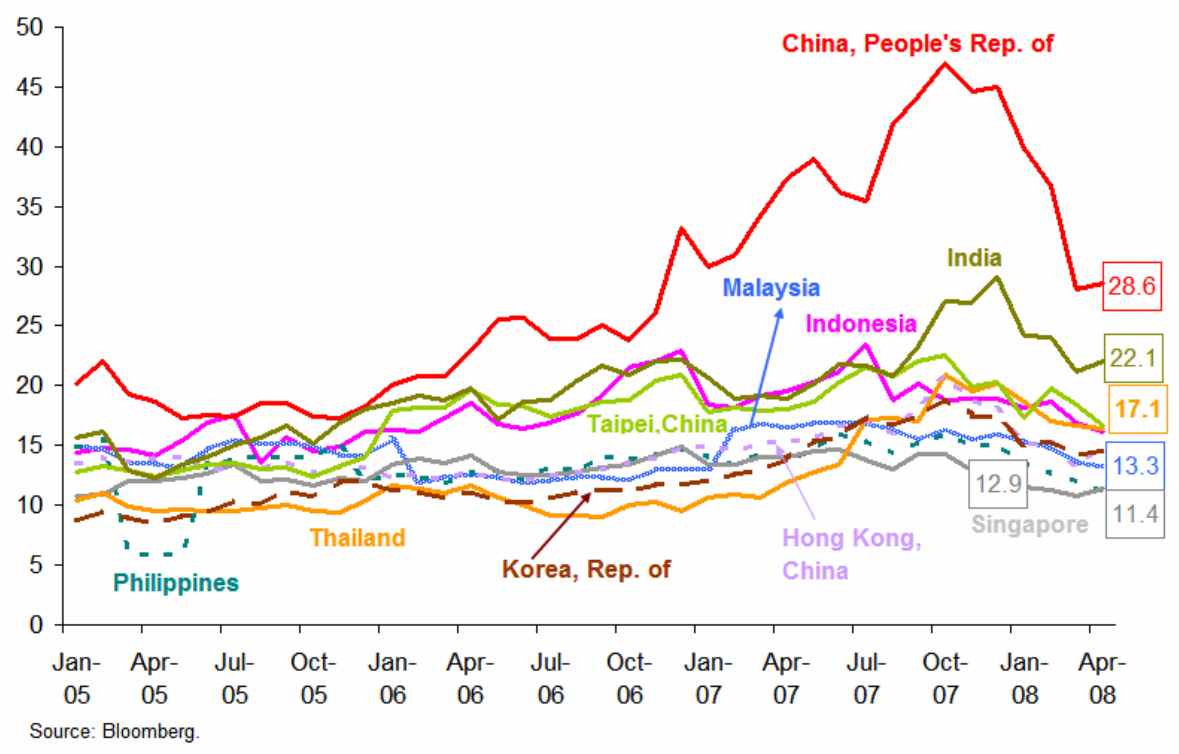

Offshore bond markets for emerging Asian issuers have also experienced a significant repricing of credit and liquidity risk since the turmoil broke out last year. Reflecting generally heightened risk aversion, credit spreads on high-risk borrowers, including emerging Asian market borrowers, have widened sharply (Figure 6). Indonesian and Pakistan bonds have been among the worst hit, but the adverse effects region wide have been broad. Offshore bond issuance by emerging Asian issuers has also generally dropped (Figure 7). But the deterioration in external debt financing conditions appears so far to have had little impact on the region's local currency debt markets.

Figure 6: JP Morgan EMBI Sovereign Stripped Spreads

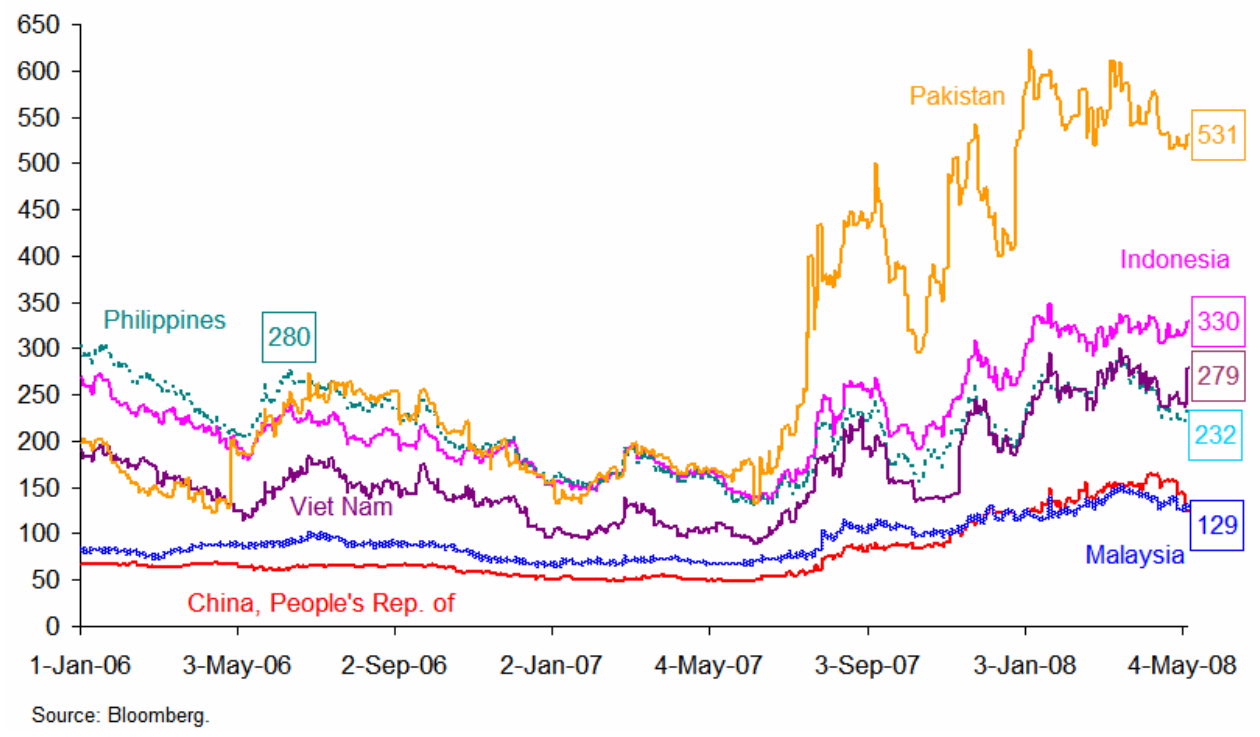


Figure 7: Private Sector Gross External Bond Issuance (\$ Billion)

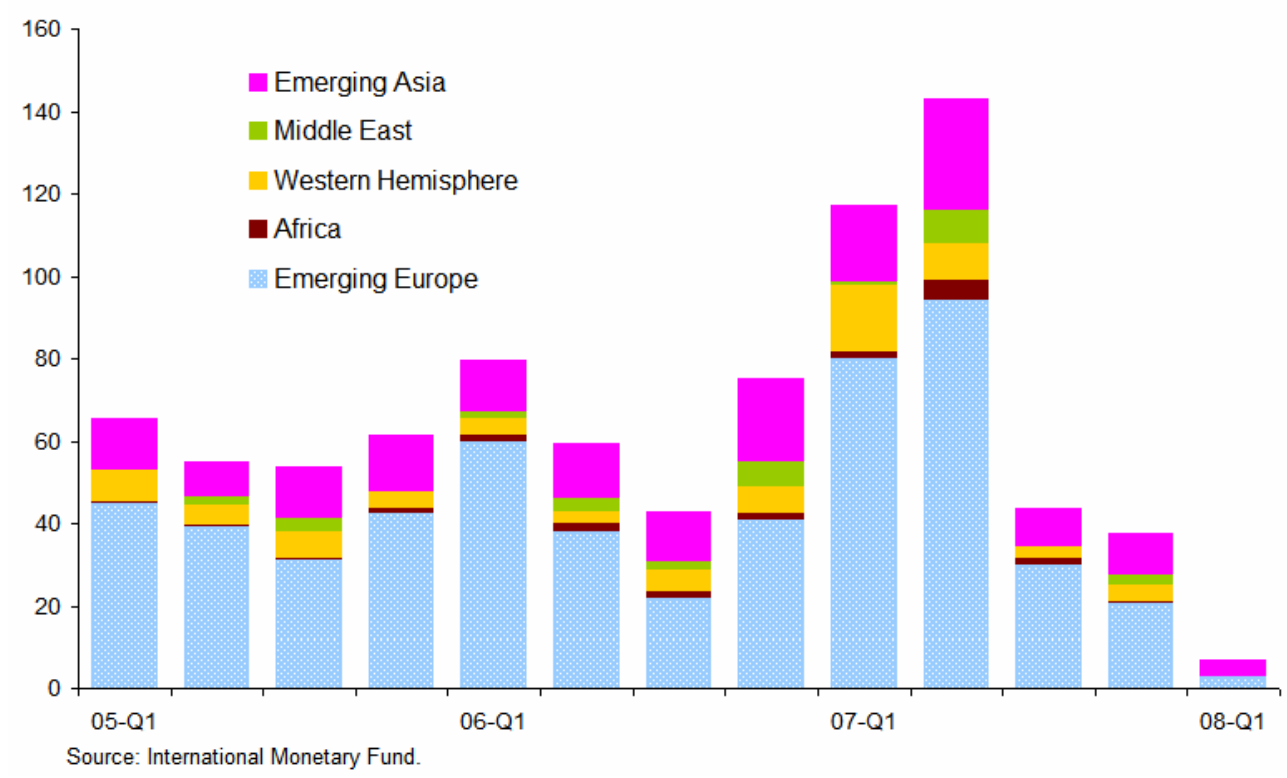

The region's banking systems entered this period of financial turbulence in relatively good health, their financial resilience underpinned by limited exposure at the origins of the problem. ${ }^{4}$ Tables $1 \mathrm{~A}-\mathrm{C}$ report the overall improvement of the region's banking systems-in their financial soundness. Their balance sheets appear healthy and little affected by the unsettled conditions in major financial markets. Nonperforming assets have declined dramatically across the region since the 1997/98 Asian financial crisis. Risk-weighted capital adequacy ratios are higher. Postcrisis reforms and restructuring of banks and once-highly-leveraged firms resulted in visible improvements in balance sheet structures. Banks have reduced short-term external borrowings - which had previously exposed them to risks stemming from currency and maturity mismatches. And they have now broadened income sources by diversifying into new, more profitable lines of business such as consumer lending and real estate, new types of financial services, and stronger fee structures.

\footnotetext{
4 Regional banking systems have reported relatively small direct exposure to subprime-related losses compared to their western counterparts, but that exposure is on the rise. According to Japan's financial regulator, the Financial Services Agency, its financial institutions' losses from the US subprime crisis nearly tripled the initial estimate, amounting to a total of $\$ 4.1$ billion in the final quarter of 2007. Japan's two biggest banks-Mizuho Financial Group Inc. and Mitsubishi UFJ Financial Group, Increported much larger losses. Fairly substantial exposure to the subprime debt has also been unveiled in some large People's Republic of China banks, including Bank of China, which recently reported a holding of about $\$ 5.0$ billion worth of subprimerelated assets. Industrial and Commercial Bank of China reportedly wrote off subprime-related losses amounting to $30 \%$ of its $\$ 1.2$ billion, while China Construction Bank set aside reserves equal to $40 \%$ of its $\$ 1$ billion in subprime holdings to cover possible losses. Woori Bank, of the Republic of Korea also reported a loss of \$445 million, of \$491 million in assets linked to subprime loans and collateralized debt obligations.
} 
Table 1A: Nonperforming Loans (\% of Commercial Bank Loans)

\begin{tabular}{|c|c|c|c|c|c|c|}
\hline & 1998 & 2003 & 2004 & 2005 & 2006 & $2007^{1}$ \\
\hline China, People's Rep. of ${ }^{2}$ & $28.5^{3}$ & 17.8 & 13.2 & 8.6 & 7.1 & 6.2 \\
\hline Hong Kong, China ${ }^{4}$ & 5.3 & 3.9 & 2.3 & 1.4 & 1.1 & 0.9 \\
\hline India & 14.4 & 9.1 & 7.2 & 4.9 & 3.5 & 2.7 \\
\hline Indonesia & 49.2 & 8.2 & 5.7 & 8.3 & 7.0 & 4.6 \\
\hline Korea, Rep. of & 7.6 & 2.2 & 1.7 & 1.1 & 0.8 & 0.7 \\
\hline Malaysia $^{4}$ & 10.3 & 8.3 & 6.8 & 5.6 & 4.8 & 3.2 \\
\hline Philippines $^{4}$ & 10.4 & 14.1 & 12.7 & 8.2 & 5.7 & 4.5 \\
\hline Singapore & $5.3^{3}$ & 6.7 & 5 & 3.8 & 2.8 & 1.8 \\
\hline Thailand & 42.9 & 12.8 & 10.9 & 8.3 & 4.1 & 3.9 \\
\hline \multicolumn{7}{|l|}{ Memo } \\
\hline Germany & 3.0 & 5.2 & 4.9 & 4.0 & 3.4 & $\ldots$ \\
\hline Japan $^{5}$ & 5.4 & 5.2 & 2.9 & 1.8 & 1.5 & 1.5 \\
\hline U.S. & 1.0 & 1.1 & 0.8 & 0.7 & 0.8 & 1.1 \\
\hline \multicolumn{7}{|c|}{ Memo items: compromised assets ratio (Indonesia) and nonperforming assets ratio (Philippines) } \\
\hline Indonesia & & 19.4 & 14.2 & 15.6 & $16.0^{6}$ & $\ldots$ \\
\hline Philippines & $\ldots$ & 26.1 & 24.7 & 19.7 & $18.6^{7}$ & $\ldots$ \\
\hline
\end{tabular}

Notes: $(\ldots)=$ not available.

1 Data for Hong Kong, China; Republic of Korea; Japan; Singapore; and the United States as of Sep 2007.

2 1999-2001 data are for state-owned commercial banks only.

3 Figure refers to 1999 data.

4 Reported nonperforming loans are gross classified loan ratio of retail banks.

5 End of fiscal year, (Mar of the following calendar year).

6 As of Sep 2006.

7 As of Jun 2006.

Sources: National sources; CEIC; and Global Financial Stability Report, International Monetary Fund. 
Table 1B: Risk-Weighted Capital Adequacy Ratios (\% of Risk-Weighted Assets)

\begin{tabular}{lrrrrrr}
\hline & $\mathbf{1 9 9 8}$ & $\mathbf{2 0 0 3}$ & $\mathbf{2 0 0 4}$ & $\mathbf{2 0 0 5}$ & $\mathbf{2 0 0 6}$ & $\mathbf{2 0 0 7}^{\mathbf{1}}$ \\
\hline Hong Kong, China & 18.5 & 15.3 & 15.4 & 14.9 & 14.9 & $13.6^{2}$ \\
India & 11.6 & 12.7 & 12.9 & 12.3 & 12.3 & 12.6 \\
Indonesia & -13.0 & 19.4 & 19.4 & 20.5 & 20.5 & 19.3 \\
Korea, Rep. of & 8.2 & 11.2 & 12.1 & 12.7 & 12.7 & 12.9 \\
Malaysia & 11.8 & 14.0 & 14.3 & 13.1 & 13.1 & 12.6 \\
Philippines & 17.7 & 17.4 & 18.7 & 18.5 & 18.5 & 19.4 \\
Singapore & 18.1 & 17.9 & 16.2 & 15.4 & 15.4 & 14.0 \\
Thailand & 10.9 & 14.0 & 13.0 & 14.5 & 14.5 & 14.8 \\
Memo & & & & & & \\
Germany & 10.5 & 13.4 & 13.2 & 12.2 & 12.5 & $\ldots$ \\
Japan $^{3}$ & 9.6 & 11.1 & 11.6 & 12.2 & 13.1 & 12.9 \\
U.S. $^{4}$ & 11.6 & 13.0 & 13.2 & 12.9 & 13.0 & 12.8 \\
\hline
\end{tabular}

Notes: $(\ldots)=$ not available.

1 Data for Japan, Rep. of Korea, Singapore, and U.S. are as of Sep 2007; Philippines as of Jun 2007.

2 Based on Basel II calculations. The previous years' calculations based on Basel I.

3 Major banks; end of fiscal year, (Mar of the following calendar year).

4 U.S. banks with assets greater than $\$ 1$ billiion.

Sources: National sources and Global Financial Stability Report, International Monetary Fund.

Table 1C: Rate of Return on Commercial Bank Assets (\% Per Annum)

\begin{tabular}{|c|c|c|c|c|c|c|}
\hline & 1998 & 2003 & 2004 & 2005 & 2006 & $2007^{1}$ \\
\hline China, People's Rep. of & $0.1^{2}$ & 0.3 & 0.8 & 0.8 & 0.9 & $\ldots$ \\
\hline Hong Kong, China & 0.4 & 1.4 & 1.5 & 1.6 & 1.5 & 1.7 \\
\hline India & 0.8 & 1.0 & 1.1 & 0.9 & 1.0 & 1.1 \\
\hline Indonesia & -19.9 & 2.6 & 3.5 & 2.6 & 2.6 & 2.8 \\
\hline Korea, Rep. of & -3.3 & 0.2 & 0.9 & 1.3 & 1.1 & $\ldots$ \\
\hline Malaysia & $1.1^{2}$ & 1.3 & 1.4 & 1.3 & 1.3 & $\ldots$ \\
\hline Philippines & 0.8 & 1.2 & 1 & 1.1 & 1.3 & 1.4 \\
\hline Singapore & 0.4 & 1.0 & 1.2 & 1.2 & 1.4 & 1.4 \\
\hline Thailand & -5.1 & 0.7 & 1.3 & 1.4 & 0.8 & 0.1 \\
\hline \multicolumn{7}{|l|}{ Memo } \\
\hline Germany & 0.3 & -0.1 & 0.1 & 0.3 & 0.3 & $\cdots$ \\
\hline $\operatorname{Japan}^{3}$ & -0.6 & -0.1 & 0.2 & 0.5 & 0.4 & 0.2 \\
\hline U.S. & 1.1 & 1.4 & 1.3 & 1.3 & 1.3 & 1.1 \\
\hline
\end{tabular}

Notes: $(\ldots)=$ not available.

1 Data for Japan, Singapore and U.S. as of Sep 2007; Hong Kong, China as of Mar 2007.

2 Figure refers to 1999 data.

3 End of fiscal year, (Mar of the following calendar year).

Sources: CEIC, national sources, and Global Financial Stability Report, International Monetary Fund. 


\section{B. Channels of Further Financial Contagion}

The limited spillover so far, nonetheless, partly reflects underlying weakness in the region's banking systems: financial institutions remain largely unsophisticated, with risk management systems challenged by still weak institutional and systemic support. And, in the absence of active risk management, bank lending to the private sector has become more conservative since the 1997/1998 financial crisis, although it has risen recently (Table 2). In order to prop up profitability, banks have moved into consumer lending and securities investment, exposing them to potential bubbles in local real estate and equity markets. In some countries, banks rely increasingly on capital markets for financing, rather than on retail deposits.

Potential spillover could occur as the move into such new lines of business broadens exposure to new types of market risk. Although lending to the corporate sector remains large, the share of housing and consumer credits in assets is expanding rapidly. Where the data is available, the share of household lending in total loans-which includes both mortgage-related and consumer financing - has nearly doubled since the financial crisis: in India, the Republic of Korea (Korea), and Malaysia it has nearly doubled since 2000 (Table 3). Mortgage-related lending, in particular, has increased visibly with recent housing booms across the region. Signs of stress have emerged in the household sector, as shown in high levels of household indebtedness in some countries (Table 4). In most, the level of household debt remains largely manageable when considering rapid growth of gross domestic product (GDP), household income, and financial wealth. But this does not preclude potentially disruptive adjustment to recent housing price inflation and its economic impact on some countries.

Table 2: Growth of Bank Credit to Private Sector (y-o-y, \%)

\begin{tabular}{lcrrrrr}
\hline & $\begin{array}{r}\text { Average } \\
\text { ('92 to '96) }\end{array}$ & $\mathbf{2 0 0 3}$ & $\mathbf{2 0 0 4}$ & $\mathbf{2 0 0 5}$ & $\mathbf{2 0 0 6}$ & $\mathbf{2 0 0 7}$ \\
\hline China, People's Rep. of & 27.7 & 20.8 & 11.2 & 9.2 & 14.3 & 19.3 \\
Hong Kong, China & 15.4 & -2.8 & 3.7 & 6.0 & 1.8 & 9.8 \\
India & 15.7 & 9.7 & 30.6 & 26.2 & 27.5 & 23.7 \\
Indonesia & 20.4 & 21.1 & 33.0 & 24.8 & 12.5 & 26.4 \\
Korea, Rep. of & 16.2 & 8.9 & 1.3 & 7.4 & 14.5 & 12.5 \\
Malaysia & 29.8 & 6.8 & 6.6 & 9.2 & 6.9 & 9.4 \\
Pakistan & 18.3 & 24.3 & 35.2 & 14.9 & 18.1 & 17.9 \\
Philippines & 37.2 & 1.1 & 9.3 & -2.2 & 7.4 & 4.5 \\
Singapore & 15.2 & 5.4 & 4.4 & 2.0 & 4.9 & 17.6 \\
Thailand & 25.0 & -1.3 & 11.3 & 7.7 & 4.0 & 3.9 \\
Viet Nam & $\ldots$ & 28.4 & 41.6 & 31.6 & 25.5 & 39.2 \\
Memo & & & & & & 12.9 \\
Euro Area & $\ldots$ & 5.7 & 6.5 & 9.9 & 11.4 & -0.1 \\
Japan & 2.3 & -4.3 & -2.3 & 3.0 & -0.3 & 9.5 \\
US & 4.4 & 7.2 & 10.6 & 10.6 & 9.5 & \\
\hline
\end{tabular}

Note: $(\ldots)=$ not available

Source: International Financial Statistics, International Monetary Fund. 
Table 3: Composition of Bank Lending ${ }^{1}$ (as \% of Total Domestic Credit)

\begin{tabular}{lrrrrrrrrr}
\hline & \multicolumn{3}{c}{ Housing Loans } & \multicolumn{4}{c}{ Consumer Loans } & \multicolumn{3}{c}{ Loans to Enterprise } \\
& $\mathbf{1 9 9 9}$ & $\mathbf{2 0 0 3}$ & $\mathbf{2 0 0 4}$ & $\mathbf{2 0 0 5}$ & $\mathbf{2 0 0 6}$ & $\mathbf{2 0 0 7}$ & $\mathbf{1 9 9 5}$ & $\mathbf{2 0 0 0}$ & $\mathbf{2 0 0 7}$ \\
\hline Hong Kong, China & 3.40 & 4.86 & 2.57 & 1.45 & 2.61 & 3.17 & $\ldots$ & $\ldots$ & $\ldots$ \\
India $^{2}$ & $\ldots$ & 4.03 & 12.03 & $\ldots$ & 7.20 & 11.30 & $\ldots$ & $\ldots$ & $\ldots$ \\
Indonesia $_{\text {Korea, Rep. of (commercial banks) }}$ & $\ldots$ & $\ldots$ & 9.47 & $\ldots$ & $\ldots$ & 28.33 & $\ldots$ & $\ldots$ & 53.20 \\
Korea, Rep. of (all banks) & $\ldots$ & 11.29 & 7.86 & $\ldots$ & 27.66 & 43.03 & $\ldots$ & 56.47 & 47.31 \\
Malaysia & $\ldots$ & 17.77 & 29.36 & $\ldots$ & 20.12 & 18.81 & $\ldots$ & 62.11 & 51.83 \\
Philippines & $\ldots$ & 13.01 & 22.17 & $\ldots$ & 0.88 & 0.44 & $\ldots$ & & 28.71 \\
Singapore & $\ldots$ & 1.86 & 2.14 & $\ldots$ & $\ldots$ & 10.11 & 65.39 & 64.16 & 48.56 \\
Taipei,China & 16.04 & 25.03 & 31.33 & & & 13.92 & & & 54.75 \\
Thailand & $\ldots$ & 19.94 & 27.30 & $\ldots$ & 14.22 & 13.27 & $\ldots$ & 40.71 & 40.78 \\
Memo & $\ldots$ & $\ldots$ & 12.25 & $\ldots$ & 0.00 & 12.25 & $\ldots$ & $\ldots$ & $\ldots$ \\
Euro Area & & & & & & & & & \\
Japan & $\ldots$ & 27.08 & 30.87 & $\ldots$ & 6.86 & 5.55 & $\ldots$ & $\ldots$ & $\ldots$ \\
US & 11.02 & 15.54 & 24.27 & 3.27 & 2.43 & 1.97 & $\ldots$ & 76.98 & 68.14 \\
& 3.23 & 3.35 & 7.12 & 18.79 & 13.96 & 11.93 & 27.49 & 27.91 & 21.08 \\
\hline
\end{tabular}

Notes: $(\ldots)=$ not available.

1 Banks include all banks for Hong Kong, China and Taipei,China; scheduled commercial banks for India; commercial banks for Indonesia, Malaysia, Philippines, Thailand, and US; domestic licensed banks for Japan; domestic banking units for Singapore; and monetary financial institutions for Euro area.

2 Latest data is for 2006.

Sources: CEIC, Bank of Korea and Financial Supervisory Service (Korea).

An increase in the share of banks' security holdings and their investment banking-type activities also implies greater market risk. Regional banks are actively participating in securities-related transactions-for example, underwriting, dealing, and brokerage-foreign exchange transactions, leasing, and insurance activities. With government efforts to develop local currency bond markets, banks are also often encouraged to take part in the development of the local bond market as issuers, underwriters, investors, and guarantors, given their dominant role in domestic financial markets. The broader scope of bank activities exposes them to new risks. Figure 8 illustrates an increase in banks' security holdings, although much of the increase is due to a rise in government security holdings. In any case, a sharp pick-up in interest rates could depress bond prices, hurting the banks' profits from bond holdings.

The region also remains open to broader contagion from global financial market turbulence. Amid heightened uncertainty, a sudden shift in the direction and magnitude of financial flows is a significant concern. Financial inflows to the region remain strong, but may fluctuate more amid the repricing of financial assets due to greater risk sensitivity among investors. A sharp reversal in risk appetite could also trigger a sudden reversal of capital flows, and of particular concern, involve a potential unwinding of "carry trades". This poses a potentially greater risk to the countries that have experienced rapid growth in portfolio investment flows and asset price inflation. Growing foreign participation in local capital markets makes the region's financial markets vulnerable to changes in global financial market conditions such as sudden swings in investor sentiment (Table 5). International institutional investors also tend to unwind their positions in emerging markets when liquidity conditions deteriorate in their home countries. 
Table 4: Household Indebtedness (\% of GDP)

\begin{tabular}{lrrrrrr}
\hline & $\mathbf{1 9 9 8}$ & $\mathbf{2 0 0 3}$ & $\mathbf{2 0 0 4}$ & $\mathbf{2 0 0 5}$ & $\mathbf{2 0 0 6}$ & $\mathbf{2 0 0 7}^{\mathbf{1}}$ \\
\hline Hong Kong, China & 54.8 & 60.2 & 58.1 & 55.5 & 52.0 & 49.9 \\
India $^{2}$ & $2.7^{6}$ & 4.6 & 6.4 & 8.1 & 9.7 & $\ldots$ \\
Indonesia $^{\text {Korea, Rep. of }}$ & $4.3^{6}$ & 6.7 & 8.2 & 9.1 & 8.5 & 8.3 \\
Malaysia & 15.0 & 34.9 & 35.3 & 37.6 & 40.8 & 40.8 \\
Philippines & 37.3 & 49.2 & 50.0 & 52.5 & 53.1 & 50.8 \\
Singapore $^{3}$ & 8.9 & 4.8 & 5.2 & 4.7 & 4.2 & 4.0 \\
Thailand & $\ldots$ & $\ldots$ & 51.0 & 49.4 & 46.4 & 46.5 \\
Memo $_{\text {Euro area }}^{4}$ & $\ldots$ & $\ldots$ & 24.5 & 24.6 & 23.6 & 23.3 \\
Japan $_{\text {US }}^{5}$ & & & & & & \\
& & & & & & \\
\end{tabular}

Notes: $(\ldots)=$ not available.

1 As of 30 Sep 2007 for Hong Kong,China; Japan; Korea, Rep. of; and Philippines.

2 Refers to personal loans extended by commercial banks (outstanding credit).

3 Sum of loans for personal uses, credit cards, purchase of consumer durable goods and purchase of passenger cars for commercial banks, merchant banks \& finance companies; 2006, only data from commercial banks and merchant banks are available.

4 Refers to loans extended by Monetary Financial Institutions (MFIs).

5 Refers to outstanding consumer credit.

6 Earliest data available for Indonesia are as of 2001; India and Japan as of 2000.

Sources: National sources and CEIC.

Figure 8: Securities Investment to Total Bank Assets of Commercial Banks (\%)

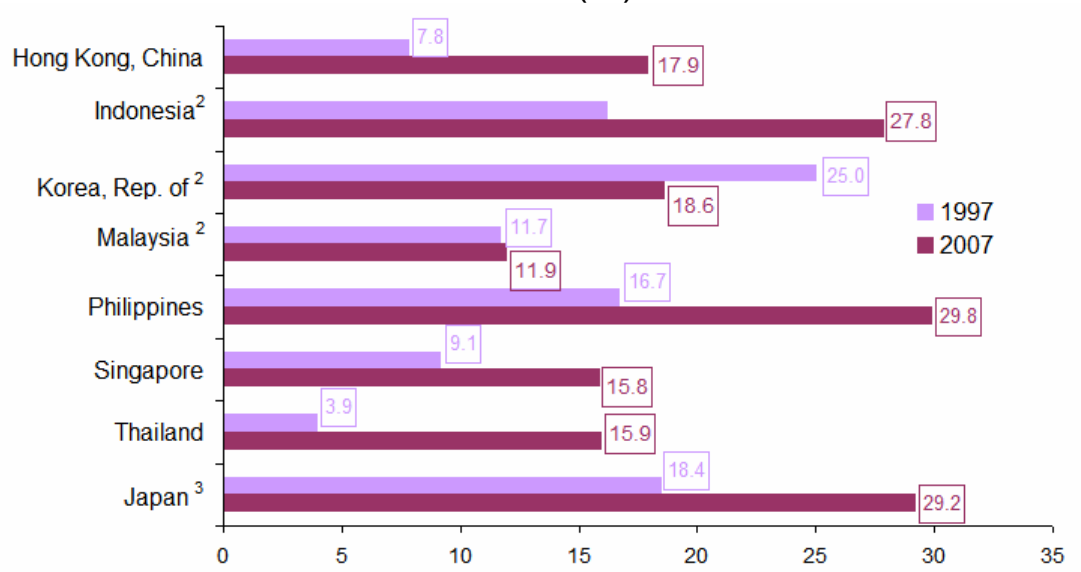

Note: For Indonesia, claims rather than securities data are used.

${ }^{1}$ Data for Philippines as of Oct 2007; Japan as of March 2007.

${ }^{2}$ Earliest data available for Mofalaysia is as of 1999; Korea as of 2000; and Indonesia as of 2001.

${ }^{3}$ End of fiscal year, (Mar of the following calendar year).

Sources: CEIC, Hong Kong Monetary Authority, Bank Indonesia, and Bangko Sentral ng Pilipinas 
Table 5: Total Portfolio Investment Liabilities (\$ Billion)

\begin{tabular}{|c|c|c|c|c|c|c|c|c|c|}
\hline \multirow[t]{2}{*}{ Economy } & \multicolumn{3}{|c|}{$\begin{array}{l}\text { Total Foreign Portfolio } \\
\text { Investment Liabilities }\end{array}$} & \multicolumn{3}{|c|}{ Domestic Capital Market } & \multicolumn{3}{|c|}{$\begin{array}{l}\text { Ratio of Foreign Portfolio } \\
\text { Investment to Domestic } \\
\text { Capital Market }(\%)\end{array}$} \\
\hline & 2001 & 2004 & 2006 & 2001 & 2004 & 2006 & 2001 & 2004 & 2006 \\
\hline China, People's Rep. of & 20.3 & 67.1 & 281.6 & 764.2 & $1,769.2$ & $1,632.6$ & 2.7 & 3.8 & 17.2 \\
\hline Hong Kong, China & 96.7 & 123.7 & 233.7 & 558.2 & 924.4 & $1,781.0$ & 17.3 & 13.4 & 13.1 \\
\hline India & 15.4 & 71.4 & 179.7 & $\ldots$ & $\ldots$ & $\ldots$ & $\ldots$ & $\ldots$ & $\ldots$ \\
\hline Indonesia & 5.5 & 25.4 & 38.9 & 72.2 & 134.5 & 226.5 & 7.6 & 18.9 & 17.2 \\
\hline Korea, Rep. of & 76.8 & 166.0 & 280.5 & 633.2 & $1,149.8$ & $1,844.8$ & 12.1 & 14.4 & 15.2 \\
\hline Malaysia & 22.6 & 51.6 & 59.4 & 201.8 & 292.3 & 382.5 & 11.2 & 17.7 & 15.5 \\
\hline Pakistan & 0.5 & 0.7 & 2.2 & $\ldots$ & $\ldots$ & $\ldots$ & $\ldots$ & $\ldots$ & $\ldots$ \\
\hline Philippines & 12.7 & 17.0 & 30.3 & 44.8 & 64.2 & 112.7 & 28.4 & 26.5 & 26.9 \\
\hline Singapore & 50.7 & 68.4 & 126.1 & 168.7 & 290.2 & 470.9 & 30.0 & 23.6 & 26.8 \\
\hline Thailand & 12.0 & 25.7 & 37.8 & 73.1 & 183.4 & 251.6 & 16.4 & 14.0 & 15.0 \\
\hline \multicolumn{10}{|l|}{ Memo } \\
\hline Euro Area ${ }^{1}$ & 542.3 & 948.6 & 1434.9 & 7774.5 & 12502.7 & 13106.2 & 7.0 & 7.6 & 10.9 \\
\hline Japan & 6308.9 & 7260.1 & 9995.9 & 13093.5 & 20412.1 & 25738.8 & 48.2 & 35.6 & 38.8 \\
\hline US & 3101.2 & 4843.6 & 6254.2 & 28886.2 & 35400.2 & 42189.6 & 10.7 & 13.7 & 14.8 \\
\hline
\end{tabular}

Notes: $(\ldots)=$ not available.

1 Euro area refers to EU 15; domestic capital market data excludes Luxembourg as data are unavailable.

Sources: Asian Bonds Online and Coordinated Portfolio Investment Survey, International Monetary Fund.

Figure 9 shows that gross capital flows to emerging Asian economies reached record highs in recent years. Large capital inflows, strong credit expansion, and adverse macroeconomic consequences are not new to emerging market economies. ${ }^{5}$ Many past episodes of financial turbulence came after asset market bubbles, including the overvaluation of many stocks and rapid credit expansion. In recent years, the changing composition of capital inflows has been worrisome. Short-term foreign capital inflows have been strong in many of the region's economies, with "other investment" inflows picking up faster. The sharp increase in the shortterm investment component of capital inflows in the mid-1990s-which was immediately withdrawn at onset of the 1997/98 financial crisis-has often been blamed as a prime reason for the crisis. In particular, large swings in the other investment category between pre- and postcrisis periods reinforced the region's awareness of risks inherent in volatile short-term financial flows.

5 See ADB (2007a). 
Figure 9: Financial Account (\% of GDP)

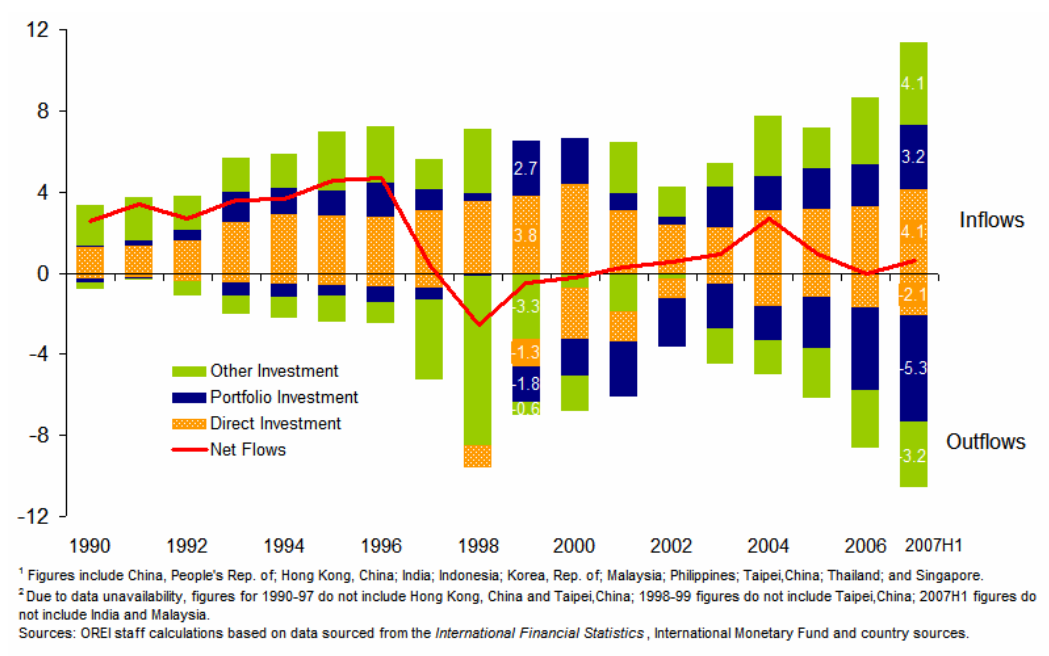

Referred to as other investments, such non-FDI, non-portfolio inflows often represent short-term borrowing of the region's banking systems and trade credits. Substantial increases in other investment inflows may also reflect increased "carry trade" activities and "hot money" driven by interest rate differentials. Although country-specific factors can partly explain recent increasessuch as a sharp rise in overseas borrowing by banks in Korea to help local shipbuilders hedge future dollar receipts-this cannot be the full story given the magnitude of the regional pattern. To the extent that the other investment component of short-term capital inflows is extremely volatile and highly interest-rate sensitive, the region's financial markets are subject to the vagaries of foreign investor sentiment.

Despite generally conservative banking activity in the region, largely unregulated non-bank financial institutions are already taking increasingly risky investment opportunities for higher returns. Local institutional investors started to increase their overseas investments and diversified their holdings into riskier and more sophisticated equity, credit, and currency derivatives. A sharp increase in portfolio investment outflows in the past few years (mainly foreign debt securities purchased by the People's Republic of China (PRC) and Korea, suggests that the exposure of the Asian economy to mortgage-related securities might be bigger than currently estimated. Higher cross-border holdings of financial assets also raise vulnerability to sharp adjustments in the valuation of global financial assets.

In globalized finance, a swing in market sentiment could also hurt local companies' funding conditions and hence investment decisions. Tighter credit conditions-together with elevated funding costs-and increased financial market volatility could squeeze funding for corporate investment, particularly where the business environment remains less friendly. So far, domestic funding conditions remain generally healthy, and the region's relatively strong banking sectors, which dominate its financial systems, provide a positive backdrop. Bank lending rates remain relatively low (Figure 10) and credits to the private sector have been strong (see Table 2). Nevertheless, heightened credit concerns are reflected in the rising costs of protecting against corporate default in emerging Asia (Figure 11). A worsening of credit conditions, potentially leading to a credit crunch, could dampen broader economic activity and, in turn, corporate profits. 


\section{Figure 10: Growth of Bank Lending Rate (\%)}

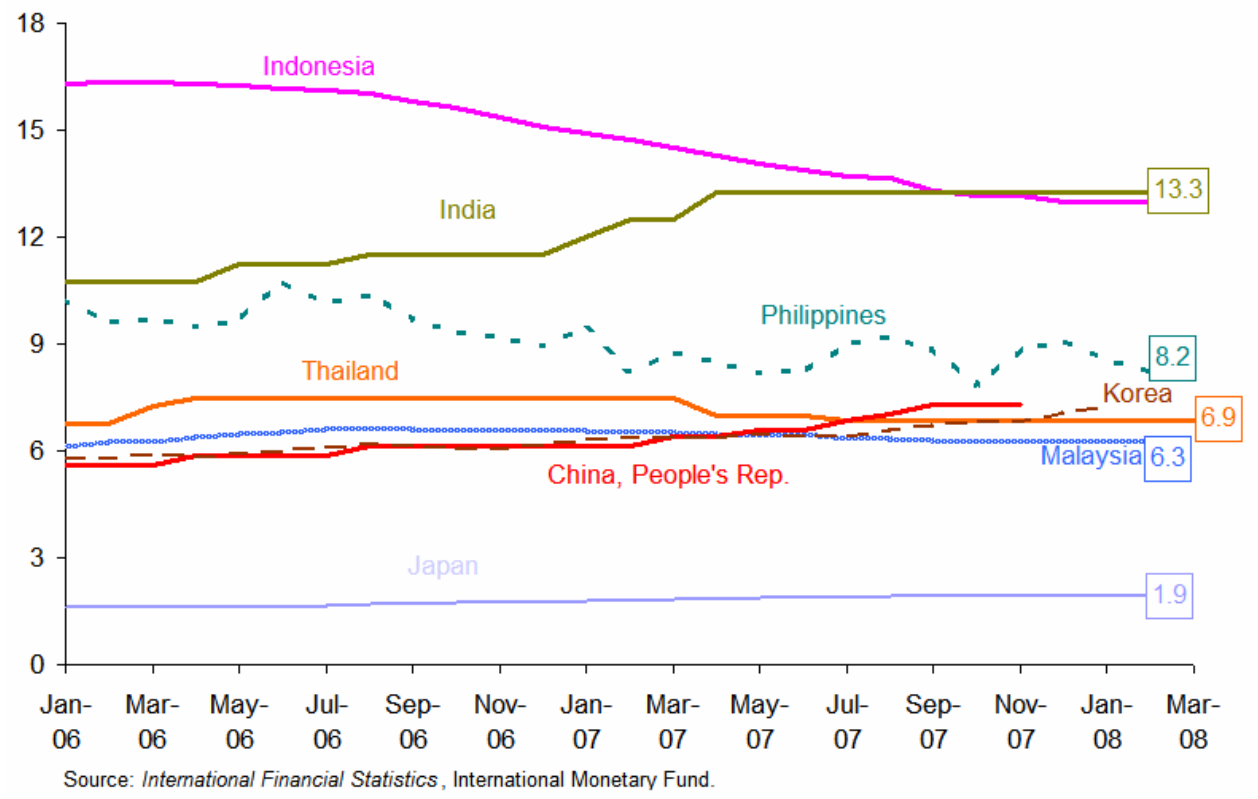

Figure 11: iTraxx ${ }^{1}$ Credit Default Swap Spreads (in Basis Points)

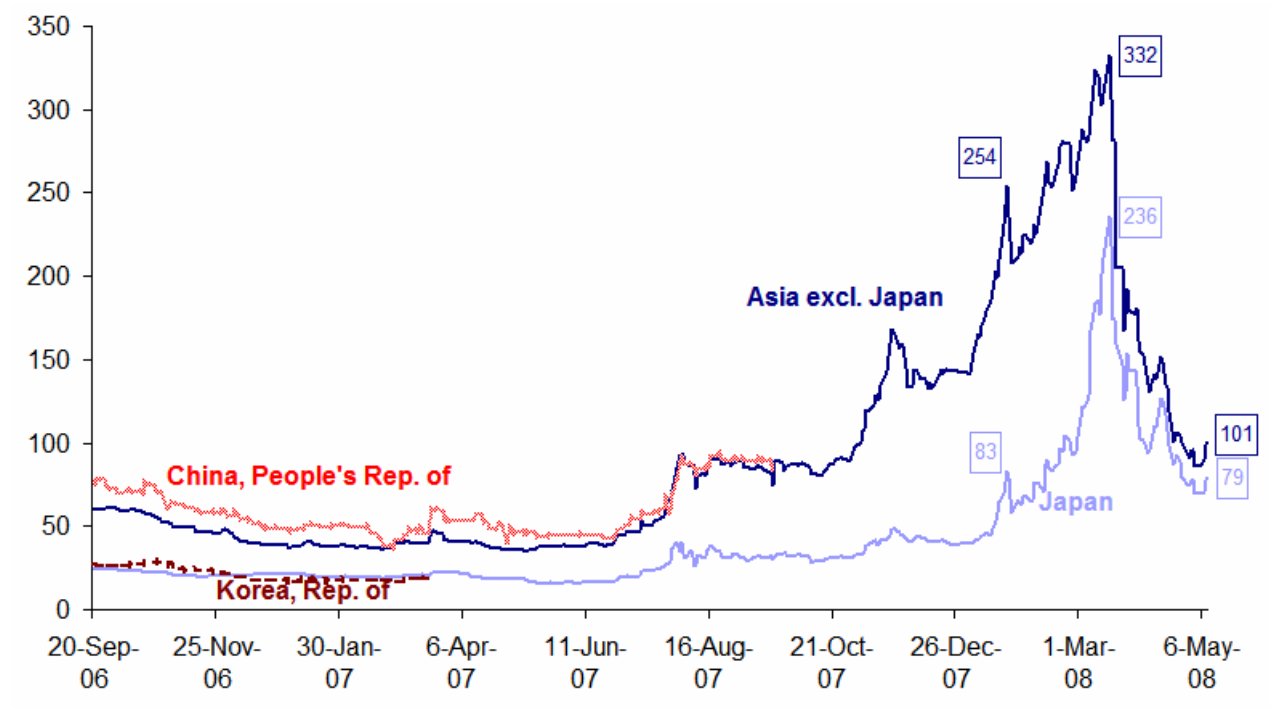

${ }^{1}$ iTraxx is the brand-name for the family of credit default swap index products covering regions of Europe, Japan and nonJapan Asia which form a large sector of the overall credit derivative market.

Source: Thomson Datastream.

\section{Challenges from the Changing Financial Landscape}

\section{A. Financial Innovation and Asian Financial Systems}

The relative strength of regional financial systems reflects a number of factors. Regional banking systems-still dominant in financial intermediation-are stronger than before: balance sheets are healthy; risk management practices are generally better; and prudential oversight has been strengthened. Prudent macroeconomic management provides a backdrop for 
currency and financial stability, with inflation targeting introduced, fiscal budgets consolidated, and exchange rate regimes made more flexible. Meanwhile, ongoing efforts to develop capital markets continue to broaden corporate financing sources, increasing the resilience of the overall financial system. But pockets of weakness remain in the region's banking and financial systems, and new challenges are emerging.

The pace of financial innovation has gathered momentum in recent years, driven by the introduction of new information and communications technologies, the evolution of consumer needs, and the removal of regulatory barriers. The result has been the introduction of new innovative financial instruments and technologies, such as securitization. Since the 1980s, securitization has become a powerful and widely used tool in both developed and emerging markets across the globe. ${ }^{6}$ The process usually uses pooled assets or income, configured to provide yield that investors find acceptable over extended periods of time and from institutions with credible credit ratings. A much wider range of instruments has meant more freedom for savers and investors to customize their financial positions to best fit their risk profile. This allows more scope for providing or acquiring funds. Markets have also grown in importance as providers of financial services, relative to banks and other traditional providers. Technological advances have also spurred globalization of finance by making it easier to invest savings around the globe and lowered the cost of financial intermediation and funding costs.

But such innovation and competition has lagged in many regional financial systems. In Asia, in the wake of the financial crisis, securitization has been used increasingly as a means to address loan losses by financial intermediaries or as a device to help bring about market-based systemic reform (Figure 12). Despite its growth, however, Asia's use of securitization is currently far more modest than Europe's or North America's. The development of auxiliary markets, such as derivatives and swaps, also lags, hampering hedging activities in the market.

Figure 12: Total Outstanding Securitization (Emerging East Asia)

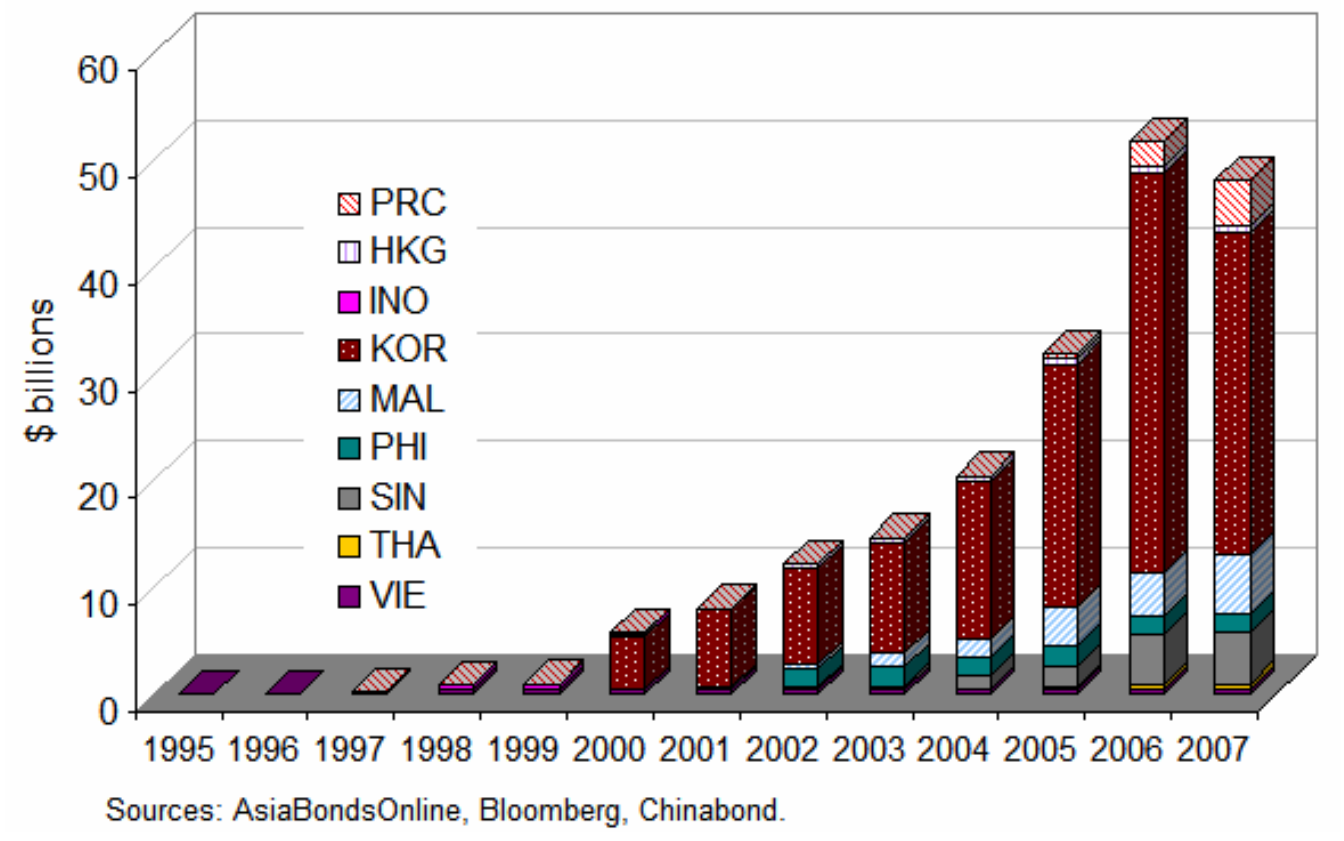

6 See ADB (2007b). 
Non-bank financial institutions-such as private investment funds, mutual and pension funds, insurance and leasing companies, and venture capital firms-while growing rapidly in recent years, ${ }^{7}$ remain underdeveloped. The size of managed assets of institutional investors remains much lower than in the US and Europe (Table 6), reflecting largely unsophisticated financial institutions in the emerging Asian region.

Table 6: Size of Markets for Institutional Investors in Integrating Asian Economies (2006)

\begin{tabular}{lrrrrrr}
\hline & $\begin{array}{c}\text { Pension } \\
\text { Funds }\end{array}$ & $\begin{array}{c}\text { Mutual Funds } \\
\text { (\$ billion) }\end{array}$ & $\begin{array}{c}\text { Life } \\
\text { Insurance }\end{array}$ & $\begin{array}{c}\text { Pension } \\
\text { Funds }\end{array}$ & $\begin{array}{c}\text { Mutual Funds } \\
\text { (\% of GDP) }\end{array}$ & $\begin{array}{c}\text { Life } \\
\text { Insurance }\end{array}$ \\
\hline China, People's Rep. of & 34.8 & 131.9 & 44.3 & 1.3 & 5.0 & 1.7 \\
India & 20.7 & 58.2 & 37.2 & 2.4 & 6.6 & 4.2 \\
Korea, Rep. of & 191.3 & 12.9 & 58.8 & 21.5 & 1.5 & 6.6 \\
Hong Kong, China & 49.5 & 713.0 & 15.3 & 26.1 & 375.3 & 8.1 \\
Singapore & 81.1 & 18.9 & 7.1 & 59.4 & 13.8 & 5.2 \\
Indonesia & 7.3 & 5.7 & 2.9 & 2.0 & 1.6 & 0.8 \\
Malaysia & 66.6 & 21.3 & 5.0 & 42.7 & 13.6 & 3.2 \\
Philippines & 0.4 & 1.2 & 0.9 & 0.3 & 1.0 & 0.8 \\
Taipei,China & 170.3 & 65.0 & 41.3 & 46.6 & 17.8 & 11.3 \\
Thailand & 10.3 & 29.0 & 3.5 & 5.0 & 14.0 & 1.7 \\
Emerging Asia & 632.3 & 1057.1 & 216.3 & 10.6 & 17.8 & 3.6 \\
& & & & & & \\
Memo & & & & & & \\
EU15 & 3433.2 & 7445.8 & 887.9 & 25.4 & 55.2 & 6.6 \\
Japan & 1439.2 & 578.9 & 378.5 & 32.9 & 13.2 & 8.6 \\
US & 9721.1 & 10413.6 & 533.6 & 73.6 & 78.9 & 4.0 \\
\hline
\end{tabular}

Sources: Country Finance 2006 \& 2007 Reports, Economist Intelligence Unit; World Economic Outlook Database (April 2008), International Monetary Fund; Swiss Re, Sigma 4/2007; Investment Company Institute, 2007 Investment Company Factbook; OECD, Pension Markets in Focus: November 2007, Issue 4.

The rapid penetration of financial innovation into parts of largely underdeveloped domestic financial systems is another concern. Despite its potential to create more efficient and resilient financial markets, financial innovation entails significant uncertainty by making changes in financial intermediation and market functioning. Some major financial disturbances in the past decade have occurred after innovations-imbued with overly optimistic views about benefitschallenged market participants' and regulators' understanding of risk. A lack of institutional capacity among financial institutions and regulators is another factor that can hamper effective risk monitoring and control, let alone the onslaught of evolving financial technology. This has led to disproportionately large damage in less developed financial systems. For example, the $1997 / 98$ financial crisis was caused in part by banks' reckless overseas borrowing, using thenmodern techniques. New and innovative investment strategies also caused large losses at

7 The size of managed assets of mutual funds and private pension funds in the newly industrialized economies (Hong Kong, China; the Republic of Korea, and Taipei,China) has risen rapidly, at about $25.4 \%$ on average, over the past 5 years, based on estimates by the Organisation for Economic Co-operation and Development and the Investment Company Institute. 
Long-Term Capital Management in 1998, the collapse of which, alongside the Russian debt default, rippled through the global financial system.

Some of the more advanced regional economies need to remain vigilant against further exposing their banking systems to risk amid the current turmoil. They must also continue to guard against spillover, while accelerating reforms to keep up with global financial market trends and developments. The region's banking and financial systems may not be as advanced as counterparts in the industrialized countries. But they continue to ride the wave of financial liberalization and globalization brought on by factors including increasing foreign investment, tightening global networks alongside the information and communications revolution, and the introduction of increasingly sophisticated financial products and services.

In this environment, prudent risk management requires the skill to assess the full magnitude and details of risk in stressful times and to prepare for extreme, yet plausible market events. Testing various stress scenarios can help gauge portfolio risks and assess potential losses under stressful market conditions. The current market turmoil presents ample evidence of just what sorts of events are plausible models for stress testing, although the underlying portfolio will determine the appropriate stress test for its risk management.

\section{B. Global Financial Integration and Spillover}

After the 1997/98 financial crisis, Asian economies took various steps to improve domestic financial systems and promote capital account liberalization. The region also took the crisis as an opportunity to deepen financial cooperation and integration at the regional level-in part as a safeguard against the spillover of global market instability, but also as a platform for regional financial development. There have been several important regional initiatives, such as the ASEAN Surveillance Process, the Chiang Mai Initiative, and the Asian Bond Markets Initiative, and Asian Bond Fund. ${ }^{8}$ Despite these efforts, regional financial integration remains limited. A number of studies find that the financial markets in Asia are more financially integrated with the global economy than with each other. ${ }^{9}$

Their increasing integration at the global rather than regional level, along with the rapid expansion of global capital markets, suggests that the potential for the financial transmission of global shocks has likely increased. But direct evidence on this point is patchy.

We test the extent of financial integration of the region's equity and bond markets with the global markets (see Appendix for the description of data, empirical methodology, and specification issues)..$^{10}$ If equity or bond markets in the region are fully integrated with global markets and no country-specific disturbances occur, stock prices or bond yields should only react to news common to all markets. The empirical results show that Asian equity markets track the US markets closely, and increasingly do so. Tighter global integration translates into increased spillover from global shocks on return on and volatility of regional equities. In contrast to equity market, the results suggest, Asian bond markets remain generally segmented from the US bond market.

\footnotetext{
8 See ADB (2008) for details.

9 Kim, Lee and Shin (2007) and Kim and Lee (2008)

10 The empirical methodology is drawn largely from European Central Bank (ECB) report on financial integration (ECB, 2008) for financial integration indicators.
} 
It is assumed that an unexpected component of individual stock market returns can be decomposed into a purely local shock (an intercept or $\alpha_{i}$ ) and a reaction to global news (proxied by an unexpected component of US market returns). If the local stock markets are integrated globally, a global shock will dominate in explaining the unexpected component of an individual market return. That is, country-specific sensitivity $\left(\beta_{i}\right)$ in the reaction to a US market shock will increase. On the other hand, the relative importance of local market shocks $\left(\alpha_{i}\right)$ will decrease. Under the assumption of complete global integration, $\alpha$ is close to zero and $\beta$ close to 1 .

Figure 13 presents the regional stock market's $\alpha$ and $\beta$-unweighted average of $\alpha_{i}$ and $\beta_{i}$ from individual stock markets. This generally confirms increasing spillover of global shocks on Asian stock market returns and the limited influence of purely local news in explaining the returns.

Figure 13: US Shock Spillover Intensity in Asian Equity Markets

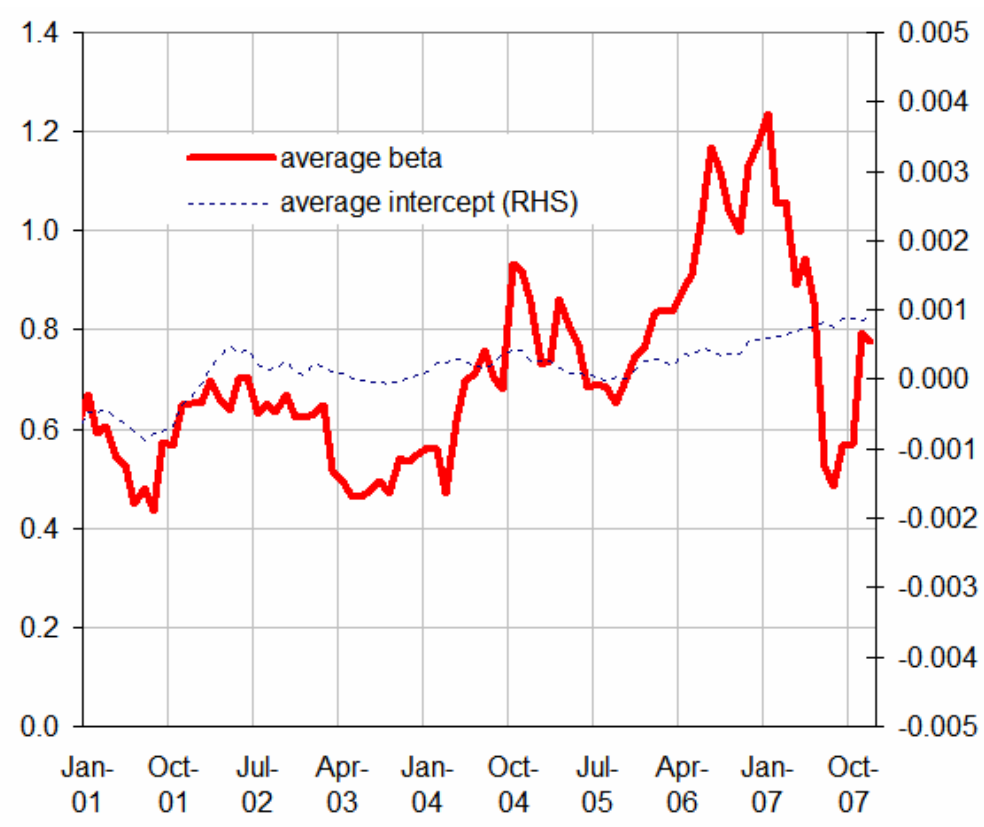

Figure 14 shows the proportion of total domestic equity market volatility explained by US shocks for the 2001-2007 period. In many emerging Asian markets, a US shock is an important force behind domestic equity volatility movements. Equity markets in Hong Kong, China; Korea; Singapore, and, to a more modest degree, Taipei,China are relatively more sensitive to volatility spillover from the US market, while comparatively less developed markets in the PRC, Indonesia, and the Philippines show lower sensitivity. In Thailand, the spillover from the US market is modest. But the Thai market experienced a spike in volatility in late 2006 and early 2007, largely due to the effect of the coup d'état in September 2006. Excluding these rather unusual observations, the portion of variance that can be explained by US shocks is higher. Overall, the rising incidence of spillover from global shocks on Asian market returns and volatility are supportive of the view that the relatively more advanced markets in emerging Asia show greater global integration. 
Figure 14: Share of Variance in Local Equity

Returns Explained by US Shocks (2001-2007)

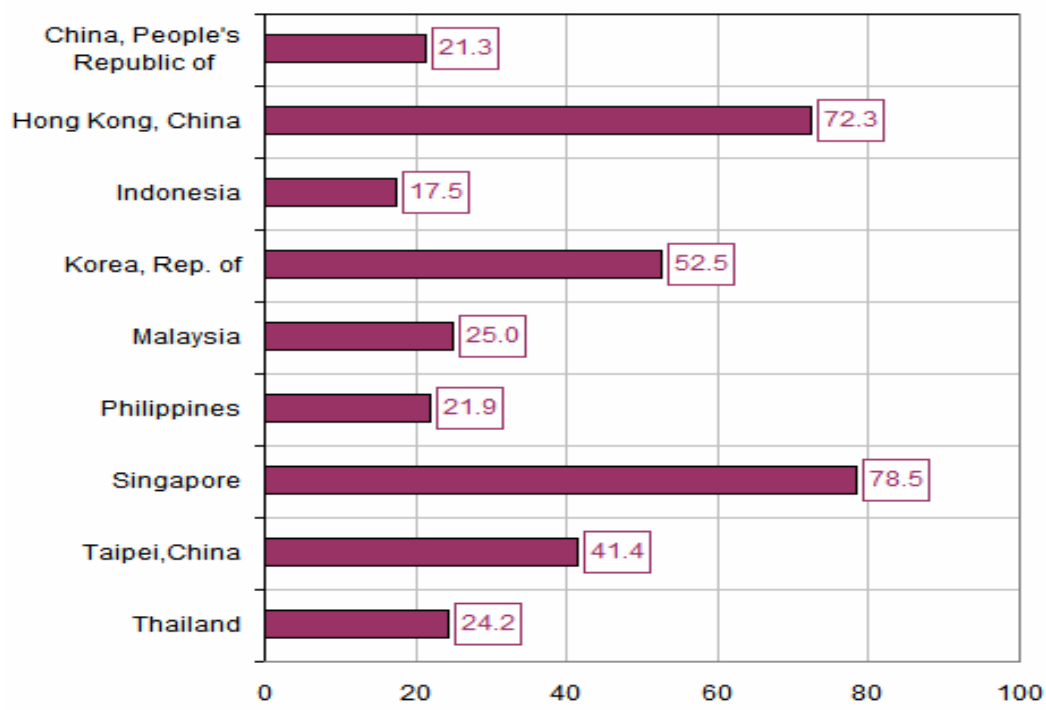

The evidence is less clear for the Asian bond markets. A model for bond yields can be constructed similar to the equity return spillover. If Asian bond markets are fully integrated with the global bond market, changes in local bond yields will simply reflect the changes in the global bond yields. Figure 15 reports the average alpha/beta from estimated individual alpha/beta for ten-year local government bond markets. The local bond markets can be said to be globally integrated if the average $\alpha$ is close to zero and $\beta$ close to 1 . The results of relatively low $\beta$ show no clear sign of global integration for ten-year Asian government bond markets during the period 2001-2007.

Figure 15: US Shock Spillover Intensity in Asian Bond Markets

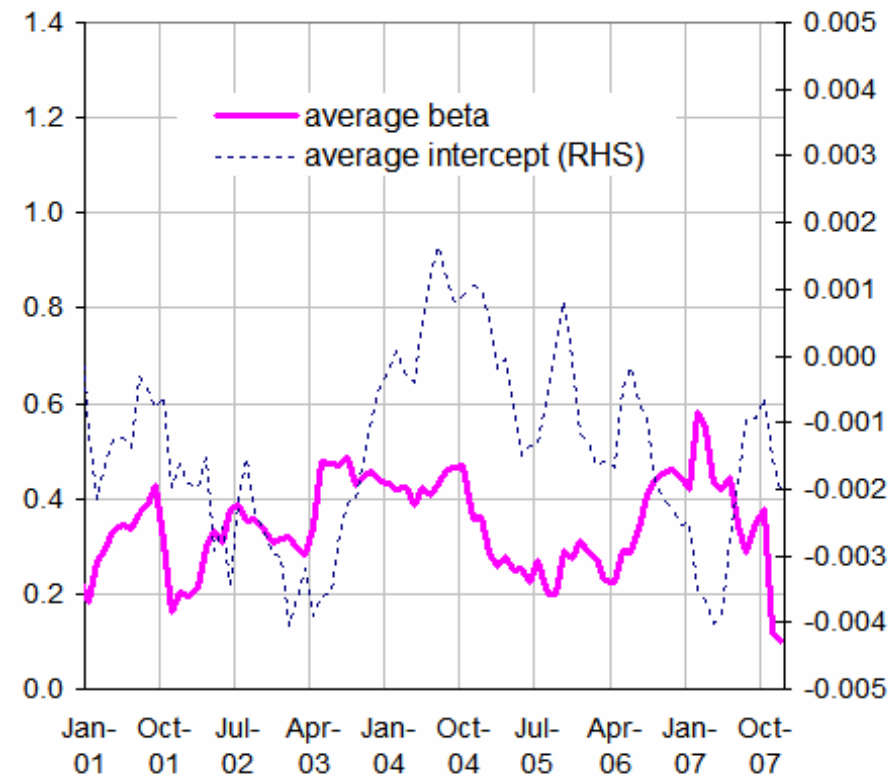


Again, in terms of volatility, local bond markets are generally not much influenced by global bond volatility. In Figure 16, the proportion of the variance of local bond yields that can be explained by global volatility is relatively small, with the notable exception of Hong Kong, China, whose monetary policy is tied to the US due to its dollar peg. And this share generally decreased in the latter period during which the recent credit turmoil likely increased US market volatility. This empirical result is consistent with other evidence that shows relative resilience of local bond markets to financial turmoil that has affected global credit markets.

Figure 16: Share of Variance in 10-Year Local Government Bond Yields Explained by US Shocks (2001-2007)

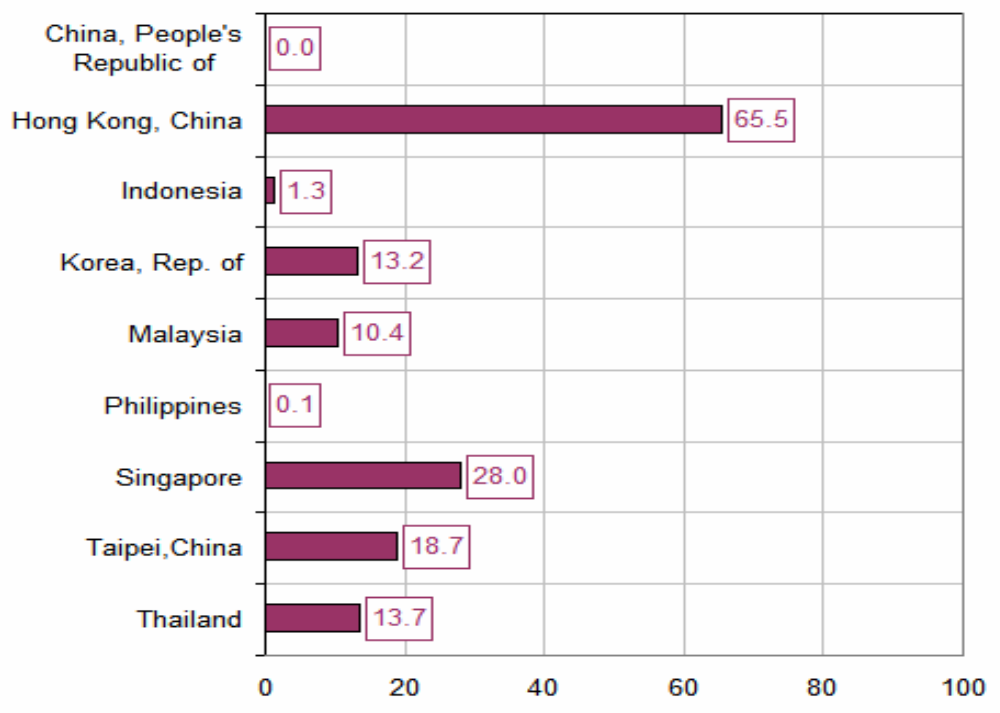

\section{Policy Implications}

The Asian financial crisis was due to the confluence of many factors, including over-reliance on bank financing and inadequate financial regulatory and supervisory frameworks. In its aftermath, a number of crucial banking reforms were undertaken to shore up banking systems in the region, making them more resilient. But more needs to be done given the increasing financial uncertainty in global markets and potential instability. Policy priorities include (i) enhancing transparency and governance; (ii) improving risk assessment and management of financial institutions; (iii) strengthening regulation and supervision; and (iv) deepening and broadening financial systems, especially by developing corporate bond markets. ${ }^{11}$

A lack of market transparency and governance infrastructure impairs investor confidence and hampers the development of domestic financial sectors. Credit risk managers in emerging markets have a difficult task: the necessary information on credit ratings and traded security

11 Recently the Financial Stability Forum (FSF), which has undertaken an analysis of the causes of the current global turmoil for the G7 ministers and central bank governors, published a report which contains recommendations for increasing the resilience of financial markets and institutions. The report (FSF, 2008) proposes concrete action in the five areas: (i) strengthening prudential oversight of capital, liquidity and risk management, (ii) enhancing transparency and valuation, (iii) changing the role and uses of credit ratings, (iv) strengthening the authorities' responsiveness to risks, and (v) robust arrangements for dealing with stress in the financial system. 
prices, for example, can be hard to come by. Many regional economies also have very limited default history data and provide little infrastructural support, such as credit information bureaus. Even where data is available, drastic changes in the economic environment in which banks operate, across Asia since the 1990s, make it difficult to gauge default probability or exposure to defaults in the current situation. Building information and governance infrastructure-such as credit information systems, accounting and disclosure rules, and internal and external auditing systems-is essential to provide certainty and foster investor confidence in the domestic financial systems, let alone an important precondition for financial liberalization without undermining financial stability.

In light of the current turmoil in the global financial markets and the structural weaknesses of regional banking systems, it is important to strengthen the banking sector and build institutional and systemic support for effective risk management. Special attention is needed for some recent and notable changes in the region's banking, such as rising household lending and securities transactions. Rapid expansion by financial institutions into unfamiliar areas inevitably entails new types of risk. Recent trends in the global financial system-importantly the growing presence of non-bank financial institutions and proliferation of new instruments for risk transfer-will also become increasingly relevant in the region.

Regulators need to renew efforts to test the capacity of their regulated institutions to manage the risks they assume, and to explore the dynamics and sensitivities of the assets they hold. They need to better understand the collateral's character and the tranching structure, particularly if instruments are difficult to value or have illiquid secondary markets. Regulators should also be better able to audit the risk management systems used by these institutions, to verify that they are appropriately tailored to individual risks.

The expansion of the services of credit rating agencies into the region's markets, for example, can help investors make sound investment decisions on adequate and fair information and is an important element of the necessary infrastructure for financial market stability. The increasingly complex product structures of modern financial assets, however, increase challenges facing credit rating agencies. Furthermore, as the issuers of these complex securities are often the clients for the agencies, there is potential for conflicts of interest. The agencies must remain independent of political or client pressure. This requires having financial independence based on adequate capital and diverse income sources.

Strengthening regulatory and supervisory frameworks is particularly important for emerging Asian markets, which face relatively weak financial market infrastructure for credit risk assessment and effective risk management. It is critical that the minimum capital requirements are met for regulated financial institutions. But more importantly, implementation of a rigorous supervisory review process needs to ensure banks maintain sound balance sheets and exercise due vigilance in their risk management practices. Adequate institutional reforms need to ensure that systemic supports, such as credit information and credit rating systems, are in place.

This is the approach taken by the Basel Committee-to steer the supervisory focus onto better risk management. As supervisory authorities embrace a more risk-focused approach in the way financial institutions deploy their own resources, firms will be given greater incentives to invest in more sophisticated risk-management systems. And enhanced transparency can encourage market discipline in monitoring the banks' risk-taking behavior. It should enable markets to reward financial institutions that take responsible approaches to risk management and penalize those that do not. A well-established governance structure for clear accountability is particularly 
important for those with more advanced financial systems, where the increasing complexity of financial services and products further complicates regulatory tasks.

A lack of institutional capacity in both financial institutions and regulators is another factor that hampers proper risk monitoring and controls, let alone dealing with evolving financial technology. The region's financial institutions should recognize that complex operations require well-established and refined internal risk management and control processes. It is also important to have knowledgeable staff to monitor risk exposure by setting effective risk limits and clearly communicating with executive management and boards of directors. Capacity building in the regulatory and supervisory bodies is essential to enable effective monitoring of risk exposure and safeguarding systemic stability against a rapidly changing financial environment.

Finally, broadening financial sectors and deepening the markets remain important long-term items on the agenda for creating more efficient and resilient domestic financial systems. One of the most valuable lessons of the Asian financial crisis was the need to deepen and diversify financial systems and markets. Prior to the crisis the region's financial system concentrated on banking, which relied heavily on short-term foreign currency debt to finance long-term investment projects in domestic currency. This exposed the financial system to systemic risk. Despite considerable progress since the 1997/98, however, Asian financial systems remain bank-dominated. Many domestic banking systems still tend to dominate in the composition of domestic financing. The development of liquid and well functioning capital markets offers an alternative financing source to bank loans, provides long-term domestic currency funding for investment, and helps foster financial stability.

While some Asian stock markets are as large as, or larger than other, comparable regional emerging markets, other segments of financial markets are much less developed. Money and bond markets in much of the region are illiquid and fragmented and, with the exception of Japan and Korea, local currency bond markets largely account for a much smaller share of GDP than in major economies. The growth in size of the region's local currency bond markets has been phenomenal, but the growth of the corporate bond markets has been slower than government bond markets, suggesting much remains to be done. Many markets require a broad range of reforms to increase the liquidity and efficiency of local currency bond markets. Priorities include: (i) improving the legal and regulatory frameworks to ensure transparency and investor protection; (ii) removing impediments to market entry and investment, particularly those on capital and exchange controls, and (iii) broadening and diversifying the investor base. ${ }^{12}$

Regional cooperation can support national initiatives to strengthen Asia's financial markets and overcome their fragmentation. Efforts to enhance the efficiency and stability of Asian capital markets need to be made at the regional as well as the national level, while fostering integration of national financial markets. Strengthening regional cooperation in information sharing, monitoring and surveillance, and local-currency bond market development will also help promote regional financial stability.

\footnotetext{
12 See Lee (2008).
} 


\section{References}

Asian Development Bank. 2007a. Asian Economic Monitor. July. Available at www.aric.adb.org

_. 2007b. Asia Bond Monitor. November. Available at www.asiabondsonline.adb.org/ regional/regional.php.

2008. Emerging Asian Regionalism: A Partnership for Shared Prosperity. Manila, Philippines: Asian Development Bank.

Financial Stability Forum. 2008. Report of the Financial Stability Forum on Enhancing Market and Institutional Resilience. Available: www.fsforum.org/home/home.html.

European Central Bank. 2008. Financial Integration in Europe. April. Frankfurt.

International Monetary Fund. 2008. Global Financial Stability Report. April. Washington D.C.

Kearney, C. and B. M. Lucey. 2004. International Equity Market Integration: Theory, Evidence and Implications. International Review of Financial Analysis. 13(5): pp. 571-583.

Kim, S., J-W. Lee, and K. Shin. 2007. Regional and Global Financial Integration in East Asia. In Eichengreen, B., C. Wyplosz and Y.C. Park, eds. China, Asia and the New World Economy. London: Oxford University Press.

Kim, S. and J-W. Lee, 2008. Real and Financial Integration in East Asia. ADB Working Paper Series on Regional Economic Integration 17.

Lee, J-W. 2008. Asian Bond Market Development: Recent Trends and Challenges. Mimeo. Asian Development Bank. Manila, Philippines. 


\section{Appendix}

\section{Appendix 1. Data Description}

The empirical analysis was conducted for a sample set of countries from emerging Asia, including the PRC; Hong Kong, China; Indonesia; Korea; Malaysia; Philippines; Singapore; Taipei,China; and Thailand. The US was included as a proxy for the global market.

We employed national stock market indexes ${ }^{1}$ in computing equity returns and 10-year government bond indexes for bond yields, both obtained from Bloomberg LP. Both equity returns and bond yields are measured in local currency ${ }^{2}$ with daily frequency from 01/01/2001 to $12 / 31 / / 2007$ for five trading days in a week. For the equity returns, we calculated the continuously compounded total returns, measured by the log differences of daily closing price levels such that, $\mathrm{R}_{c, t}=\ln \left(\mathrm{P}_{c, t}\right)-\ln \left(\mathrm{P}_{c, t-1}\right)$ for market $c$ on day $t$. For the bond yields, end of day values for yields-to-maturity have been collected.

\section{Appendix 2. Empirical Methodology}

\section{A. Equity Markets}

The returns of individual equity market are modeled as having an expected component and an unexpected one, $\varepsilon_{c, t}$. Following the ECB (2008) approach, the expected return is obtained by relating individual market returns to a constant term and to the returns in the previous period. The error terms from the regression constitute the unexpected component of the return, or innovation. ${ }^{3}$ The unexpected component is then decomposed into a purely local shock $\left(\alpha_{c, t}\right)$ and a reaction to global (US) news $\left(\varepsilon_{\mathrm{us}, \mathrm{t}}\right)$ :

$$
\varepsilon_{c, t}=\alpha_{c, t}+\beta_{c, t}^{u s} \varepsilon_{u s, t}
$$

where $\beta$ represents the country-specific sensitivity to US market shocks (of the unexpected component of equity returns).

It is assumed that innovation of local returns that is not explained by the common global factor is entirely due to local news. If equity markets are fully integrated globally and there is no countryspecific disturbance, all innovation will be global. That is, an unexpected component of the returns of any individual market should react exclusively to common global news, which is reflected by an unexpected component of the returns in the global (US) market. Hence, under the assumption of complete financial integration, $\alpha_{c, t}=0$ and $\beta_{c, t}^{u s}=1$.

\footnotetext{
1 Regional stock market indexes are: Shanghai Composite Index (SHCl) for China; Hang Seng Index for Hong Kong, China; Jakarta Composite Index for Indonesia; KOSPI for Korea; Kuala Lumpur Composite Index (KLCl) for Malaysia; Philippine Composite Index (PCI) for Philippines; FTSE Straits Times Index (FSSTI) for Singapore; Taiwan Stock Exchange (TWSE) Index for Taipei,China; and SET Index, Thailand. For the US market, S\&P 500 has been used.

2 Asset returns are often expressed in terms of the US dollar or any single currency in financial integration studies in light of the "law of one price." In this analysis, however, the main interest is to assess the spillover of US shocks on local markets and the impact on returns to local investors, rather than global investors, is of particular interest to local policymakers in the wake of global financial turmoil. Nonetheless, the impact of daily exchange rate volatility on the trend of financial integration or on the degree of spillovers is small. We used equity returns in dollar terms to measure spillover intensity and variance ratios in the preliminary analysis. The results from the preliminary analysis produce nearly the same trends over time, while the actual levels are only slightly different.

3 The conditional variance of the error terms is assumed to follow a standard asymmetric GARCH $(1,1)$ process.
} 
In order to investigate the development of the country-specific betas over time, time-varying betas of individual markets have been calculated for the period 2001-2007. The time-varying betas are derived by running the above regression in an 18-month rolling window. That is, the first $\beta_{c, t}^{u s}$ is estimated, using the monthly averages of equity returns for the first 18 months. Subsequently, the data window is moved one month ahead and the equation is re-estimated until the last observation is reached.

Figure 15 reports the unweighted average of $\beta_{c, t}^{\text {us }}$, for all $c$, as spillover intensity by which a US shock is transmitted to local equity markets, as well as the unweighted average of $e_{c, t}$, for all $c$, as an influence of purely local disturbance.

Figure 16 reports the variance ratios for individual market returns. This is to estimate the proportion of total domestic equity volatility explained by the global (US) shock. The conditional variance is estimated by the $\mathrm{GARCH}(1,1)$ model for individual country-specific returns. Total volatility is then given by:

$$
\sigma_{c, t}^{2}=h_{c, t}+\left(\beta_{c, t}^{u s}\right)^{2} \sigma_{u s, t}^{2}
$$

where $h_{c, t}$ is the variance of the local shock component.

The variance ratio for an individual market is then obtained by:

$$
V R_{c, t}^{u s}=\frac{\left(\beta_{c, t}^{u s}\right)^{2} \sigma_{u s, t}^{2}}{\sigma_{c, t}^{2}}
$$

The variance ratio will be close to one, if the beta approaches one and when the volatilities of the local and the US market returns are of a similar magnitude. The variance ratio is derived by assuming that local shocks are not correlated with the US market returns.

\section{B. Bond Markets}

Similarly, if bond markets are fully integrated globally and no country-specific disturbance affects credit risk, bond yields should respond only to common global markets. That is, changes in the bond yields of individual countries should react exclusively to common global news, which is reflected by a change in the global benchmark bond yield (10-year US Treasury note). To separate common from local influences, the following regression is run:

$$
\Delta R_{c, t}=\alpha_{c, t}+\beta_{c, t} \Delta R_{u s, t}+\varepsilon_{c, t}
$$

where $\alpha$ denotes a time-varying and country-dependent intercept; $\beta$ is a country-specific and time-varying beta with respect to the benchmark (US) bond yield; $\Delta \mathrm{R}$ is the change in the bond yield; and $\varepsilon$ is a country-specific shock.

A time series is obtained for $\alpha$ and $\beta$ respectively, using the same 18-month rolling regression as for the previous equity returns. 
Figure 17 reports the unweighted average of $\beta_{c, t}$, for all $c$, as well as the unweighted average of $\alpha_{c, t}$, for all $c$, respectively for the magnitude of influence of US and local market disturbance.

Again, Figure 18 shows the share of the variance of local (country-specific) bond yields that can be explained by the variance of the global benchmark yields (or 10-year US Treasury note yields). The total variance of local bond yields is given by:

$$
\operatorname{Var}\left(\Delta R_{c, t}\right)=\beta_{c, t}^{2} \operatorname{Var}\left(\Delta R_{u s, t}\right)+\operatorname{Var}\left(\varepsilon_{c, t}\right)
$$

and the variance ratio by:

$$
\operatorname{VR}_{c, t}=\frac{\beta_{c, t}^{2} \operatorname{Var}\left(\Delta R_{u s, t}\right)}{\operatorname{Var}\left(\Delta R_{c, t}\right)}
$$

\section{Appendix 3. Specification Issues}

Some important caveats should be kept in mind when interpreting the empirical results. First, the econometric methodology is subject to potential specification problems. We consider the simplest possible equations where changes in equity returns or bond yields are determined only by local and global news. Thus, many other factors that may influence rate of return to equity or bond are not specified. The omission of such factors may cause bias of parameter estimates in these parsimonious equations. Second, the empirical results depend on the selection of the most appropriate benchmark equity returns or bond yields. Here, we have employed the US market as a proxy for the global market. But the US market is not necessarily the global benchmark. Third, the assumption of the benchmark case of perfect market integration is unrealistic in that common factors cannot fully explain changes in local equity returns or bond yields. Earlier financial literature ${ }^{4}$ shows evidence of partial segmentation or time-varying integration. It is thus unlikely that reactions to local and global news can be completely separated and uncorrelated. Finally, multiple facets of financial market integration make it difficult for any single measure to provide a comprehensive assessment of market integration. It is worth noting that the methodology applied in this paper is just one among many indicators and unlikely to give a definite picture of market integration. Given the significant specification problems and technical difficulties, the empirical results should be interpreted with caution and taken as only illustrative.

\footnotetext{
4 For literature survey on international capital market integration, see Kearney and Lucey (2004).
} 


\section{ADB Working Paper Series on Regional Economic Integration ${ }^{*}$}

1. "The ASEAN Economic Community and the European Experience" by Michael G. Plummer

2. "Economic Integration in East Asia: Trends, Prospects, and a Possible Roadmap” by Pradumna B. Rana

3. "Central Asia after Fifteen Years of Transition: Growth, Regional Cooperation, and Policy Choices" by Malcolm Dowling and Ganeshan Wignaraja

4. "Global Imbalances and the Asian Economies: Implications for Regional Cooperation" by Barry Eichengreen

5. "Toward Win-Win Regionalism in Asia: Issues and Challenges in Forming Efficient Trade Agreements" by Michael G. Plummer

6. "Liberalizing Cross-Border Capital Flows: How Effective Are Institutional Arrangements against Crisis in Southeast Asia" by Alfred Steinherr, Alessandro Cisotta, Erik Klär, and Kenan Šehović

7. "Managing the Noodle Bowl: The Fragility of East Asian Regionalism" by Richard E. Baldwin

8. "Measuring Regional Market Integration in Developing Asia: a Dynamic Factor Error Correction Model (DF-ECM) Approach" by Duo Qin, Marie Anne Cagas, Geoffrey Ducanes, Nedelyn Magtibay-Ramos, and Pilipinas F. Quising

9. "The Post-Crisis Sequencing of Economic Integration in Asia: Trade as a Complement to a Monetary Future" by Michael G. Plummer and Ganeshan Wignaraja

10. "Trade Intensity and Business Cycle Synchronization: The Case of East Asia" by Pradumna B. Rana

11. "Inequality and Growth Revisited" by Robert J. Barro

12. "Securitization in East Asia" by Paul Lejot, Douglas Arner, and Lotte Schou-Zibell

13. "Patterns and Determinants of Cross-border Financial Asset Holdings in East Asia" by Jong-Wha Lee

14. "Regionalism as an Engine of Multilateralism: A Case for a Single East Asian FTA" by Masahiro Kawai and Ganeshan Wignaraja

15. "The Impact of Capital Inflows on Emerging East Asian Economies: Is Too Much Money Chasing Too Little Good?" by Soyoung Kim and Doo Yong Yang

16. "Emerging East Asian Banking Systems Ten Years after the 1997/98 Crisis" by Charles Adams

17. "Real and Financial Integration in East Asia" by Soyoung Kim and Jong-Wha Lee

* These papers can be downloaded from: (ARIC) http://aric.adb.org/reipapers/ or (ADB) http://www.adb.org/ publications/category.asp?id=2805 






\section{About the Asian Development Bank}

ADB's vision is an Asia and Pacific region free of poverty. Its mission is to help its developing member countries substantially reduce poverty and improve the quality of life of their people. Despite the region's many successes, it remains home to two thirds of the world's poor. Nearly 1.7 billion people in the region live on $\$ 2$ or less a day. ADB is committed to reducing poverty through inclusive economic growth, environmentally sustainable growth, and regional integration.

Based in Manila, ADB is owned by 67 members, including 48 from the region. Its main instruments for helping its developing member countries are policy dialogue, loans, equity investments, guarantees, grants, and technical assistance. In 2007, it approved $\$ 10.1$ billion of loans, $\$ 673$ million of grant projects, and technical assistance amounting to $\$ 243$ million.

\section{About the paper}

In this paper, Jong-Wha Lee and Cyn-Young Park examine the US subprime-generated turmoil and its potential spillover on emerging Asia's financial markets. They show that while these markets have thus far suffered only limited impact, they remain open to further contagion given underlying weaknesses in the region's financial systems.

Asian Development Bank

6 ADB Avenue, Mandaluyong City

1550 Metro Manila, Philippines

www.adb.org

Publication Stock No. PPA202308

Printed in the Philippines 